\title{
Material Apotheosis: The Editions of the Divine Pivot Ready to Hand and the Ritual Underpinnings of Zhu Quan's Divine Authorship*
}

\author{
BONY B. SCHACHTER
}

Yuelu Academy / Hunan University, Lushan South Road, Yuelu District, Changsha, Hunan Province, China, 410082

E-mail: bonyschachter@outlook.com

Received: September 15, 2019 Accepted: June 5, 2020

(C) 2020 The Author

\section{ABSTRACT}

This contribution argues that Zhu Quan's (1378-1448) apotheosis must be interpreted as a paratextual discourse on authorship. Substantiating this claim, this article discusses how the extant editions of the Divine Pivot Ready to Hand construct the king's divine authorship. In its three sections, the article examines the physical, paratextual and ritual dimensions of his apotheosis. Focusing on the last chapter of the Pivot, it demonstrates that calendars serve as a material cum textual media through which to posit Zhu Quan's divine status. In a dialogue with the field of ritual studies, the article explains to what degree Zhu Quan's calendars may be interpreted as an act of ritual textualisation.

\section{KEY WORDS}

Daoism, Materiality, Print Culture, Ritual, Apotheosis, Zhu Quan, Zhouhou shenshu.

* This article is a modified version of the fifth chapter of my Ph.D. dissertation, 'The TQYC and Its Redaction: Nanji Chongxu Miaodao Zhenjun, Longevity Lore, and the Consolidation of Ancestorship', in Schachter 2018a: 377-480. A research grant received upon the completion of my dissertation (ICS Mok Hing Cheong Postgraduate Scholarship) allowed me to revise significant portions of this article in Jerusalem and Paris, places that 'have outstandingly dry air' and 'clear skies', which are of great benefit for scholarly activities. Heartfelt thanks to Lai Chi-Tim 黎志添 for his support and guidance during the years I spent in the Centre for Studies of Daoist Culture, CUHK, as his student. Professor Lai remains a constant source of inspiration and a model of Daoist scholarship. John Lagerwey generously read the final draft of this article. His constructive criticism and timely corrections saved me from embarrassing errors. My friend and colleague Hu Jiechen 胡劼辰 pointed many mistakes and made extremely useful remarks. My friend Judit Bagi carefully read an earlier draft of this article and offered valuable philological feedback. Doctor Martin Heijdra kindly provided me a digital copy of his illuminating article about the aesthetic dimension of Chinese printed editions. Tristan G. Brown (MIT History) offered extremely useful feedback in a matter of days. Last but not least, I must thank the anonymous reviewers of $\mathrm{AOH}$ for their comments and suggestions. 


\title{
1. INTRODUCTION
}

Zhu Quan 朱權 (1378-1448) is one of the most remarkable authors of fifteenth-century world literature. In 1391, his father, the Ming founder Zhu Yuanzhang 朱元璋 (1328-1398), invested him as the King ${ }^{1}$ of Ning 寧王. In 1403, the usurper Zhu Di 朱棣 (1360-1424) shifted Zhu Quan's kingdom to Nanchang 南昌, where the prolific king printed books on music, history, drama, poetry, medicine, and Daoism. He was stationed there until his death. ${ }^{2}$ Zhu Quan was one of the foremost intellectual architects of Ming triumphalism and the self-appointed porte-parole of what Lagerwey (2016: 113-129) has termed the Ming double orthodoxy. Despite the relevance of his oeuvre, the king remains a rather understudied author. ${ }^{3}$ Consequently, the many subtleties that surround his authorship are poorly understood. Focusing on the materiality of Zhu Quan's apotheosis as a Daoist god, this article examines how the extant editions of the Divine Pivot Ready to Hand ${ }^{4}$ (Zhouhou shenshu 肘後神樞; hereafter, Pivot) construct his divine authorship as the Perfected Lord of the Wondrous Path of the Unfathomable Void from the Southern Pole ${ }^{5}$ (Nanji Chongxu Miaodao Zhenjun 南極沖虛妙道真君, hereafter, Perfected Lord).

The king wrote intriguing passages on the apparent immateriality of his apotheosis. Addressing the new emperor $\mathrm{Zhu} \mathrm{Di},{ }^{6}$ he describes his relationship with the divine world as follows:

\begin{abstract}
某自太清初下, 天閭之時, 群真送之。友愛之情, 眷念不已。臨歧之囑, 某尚不 忘, 自謂天地間, 近世與吾同道者, 未遇一人。故緘口無一字可道。每思天上群 真, 不能攜手一相笑耳。但日常仰瞻南極, 未嘗不為之矯首興歎。

In the beginning, I descended from the Great Clarity. When [we] arrived ${ }^{7}$ at the Celestial Pavilion, the myriads of Perfected Ones escorted me [on my way out]. [Due to] sentiments of friendship and love, [I] feel deeply nostalgic. I have never been able to forget the exhortations made at the time of parting. I claim that between heaven and earth, I have never met in recent times a single person engaged in the same Path. Therefore, I kept silent, being unable to proffer a single word. When I think about the cohorts of Perfected Ones on Heaven above, [I realise that we] cannot hold hands and laugh together [anymore]! I look up and contemplate the Southern Pole daily; I always lift my head high and sigh by reason of it! ${ }^{8}$
\end{abstract}

${ }^{1}$ In previous works, I tended to favor the translation 'prince' over 'king', for the term wang 王. However, I am convinced that Clunas' (2013: 7-24) translation of the term wang as 'king', apart from representing a more elegant solution, is also a more accurate rendition into English.

2 On Zhu Quan, see Jonker 1976: 307; Ho and Zhao 1983; Idema 1986; Yao 2002; Boltz 2008b: 1294-95; Wang 2012: xi-xix; Clunas 2013: 22, 53-54, 143, 145, 181; and Meulenbeld 2015: 146. For a detailed biographical reconstruction, see Schachter 2018a: 83-173. On Ming kings, see Robinson 2012: 1-12.

${ }^{3}$ Comparatively speaking, the number of studies on Western authorship is infinitely vaster, see, for example, Burke 2003.

${ }^{4}$ For this translation of the term zhouhou, see Sivin 2015: 198.

${ }^{5}$ My translation of Zhu Quan's divine title differs slightly from Boltz 2008a: 975.

${ }^{6}$ This excerpt is a paratext to the book Divine Hermitage (Shenyin 神隱). Its nostalgic tone did not move Qing scholars, for whom Zhu Quan's goal was to convince Zhu Di about his lack of political ambitions (Siku quanshu zongmu, 147.2464). Our scholars dated the letter to Yongle 6 (1408), but in extant editions the paratext does not offer its date of composition. On the ritual aspects of Chinese epistles, see Kádár 2019: 207-227. Hu Jiechen called my attention to the fact that Zhu Di may have regarded himself as a manifestation of Zhenwu 真武. In fact, in the letter mentioned above Zhu Quan does describe Zhu Di as a Daoist god. I explore this letter in detail in a book about Zhu Quan's divine authorship that I am currently preparing.

${ }^{7}$ Reading $z h i$ 之 as $z h i$ 至.

8 Shenyin, $1.3 \mathrm{~b}$. 
The paratext ${ }^{9}$ above does not explain why the divine entity descended to the human world, thus becoming a human king. But in the Jade Slips of Great Clarity on the Supreme Path of the Celestial Sovereigns (Tianhuang zhidao taiqing yuce 天皇至道太清玉冊, hereafter Jade Slips), ${ }^{10}$ his magnum opus dated 1444, Zhu Quan explains ${ }^{11}$ the circumstances of his apotheosis:

\section{余年方十有一, 在齠此時, 遇一青衣老媼, 謂曰：「爾切勿忘夙念, 六十年後方 可許開口。」余故直書其事；「日於昔在少昊之四十七年，當昭陽赤奮若之歲， 奉太清之命, 封河東冥京之主, 至商武丁三十一年, 柔兆崦茂之歲, 一千二十九 年, 上昇太清, 特進南極沖虛妙道真君, 居南極九十四宮之位, 在天二千六百九 十九年，太清授以蓬萊玉爾、太陽金符，令予下降人間，以匡天道，使振玄風， 握靈樞而闡玄化也。」12}

When I was eleven years old, at the age of shedding the milk teeth, I met an old lady in azure garments, who told me: 'You must never forget your past memories, being allowed to speak [about them] only after sixty years. ${ }^{13}$ I, therefore, directly recorded the matter: 'In times of yore, during the forty-seventh year of Shaohao, ${ }^{14}$ [which was] a Zhaoyang-Chifenruo ${ }^{15}$ year, obeying the Mandate of the Great Clarity, ${ }^{16}$ I was invested as the Lord of the Abyssal Capital of Hedong. Reaching the thirty-first year of the Shang [ruler] Wuding, ${ }^{17}$ [which was] a Rouzhao-Yanmao ${ }^{18}$ year, [after] 1029 years, I ascended to the Great Clarity as the Specially Advanced [Tejin ${ }^{19}$ ] Perfected Lord of the Wondrous Path of the Unfathomable Void from the Southern Pole, occupying the ninety-fourth rank of the Southern Pole. After I spent 2699 years in heaven, the Great Clarity conferred upon me the Jade Seal of Penglai, and the Metal Talisman of the Supreme Yang, ordering me to descend to the human realm in order to support the Celestial Way and to promote Daoism [xuanfeng]; grasping the numinous pivot, I shall explain the mysterious transformations. $\lrcorner$

The two excerpts translated above articulate a mystical relationship between Zhu Quan and the Southern Pole (Nanji 南極), also known as the Longevity Star (Shouxing 壽星), the ancient imperial god about whom Sima Qian 司馬遷 (145-86 BCE) says: 'When the Old Man [i.e., the

9 On paratexts, see Jansen 2014.

${ }_{10}$ For a discussion of its editions, see Schachter 2018b.

11 There is a second version of this testimony. Attributed to Hu Yan 胡儼 (1360-1443), a Ming official and personal acquaintance of Zhu Quan. See the Chifeng jian Nanji changsheng gong ji, in: Xishan zhi 西山志, 8.65. In Hu Yan's version, a deity appears to the Ming king, informing him directly about his divine status during the Yongle reign (r. 1402-1424). On the Yongle reign, see Chan 1998: 184-204.

12 Jade Slips, $8 \mathrm{~b}$.

13 This preface is dated 1444, when Zhu Quan was 67 sui 歲. The revelation occurred when he was 11 sui. In theory, Zhu Quan should not disclose the revelation to others before he achieved 71 sui.

14 According to transmitted documents, Shaohao 少昊 was one of the Yellow Thearch's (Huangdi黃帝) sons. In his Jade Slips, Zhu Quan describes Shaohao as one of the Five Thearchs (Wu Di 五帝). The other four Thearchs are Zhuan Xu 顓頊, Di Ku 帝礐, Di Yao 帝堯, and Di Shun 帝舜. See Jade Slips, 245a.

${ }^{15}$ In this text, Zhaoyang-Chifenruo points to a guichou 癸丑 year.

16 On the Daoist concept of Great Clarity, see Pregadio 2006: 35-51.

17 Wuding 武丁 (r. 1250-1192 BC) was the 23rd ruler of the Shang dynasty.

18 Rouzhao-Yanmao stands for a bingxu 丙戌 year. The 1607 edition of the Jade Slips renders 'yan' in yanmao as yan 崦. Usually, this is written as yan 閹.

19 The term tejin 特進 is associated with high ranks of the Ming administration. See Hucker 1985: 490, where tejin is translated as 'Lord specially advanced'. 
Southern Pole] appears [in the sky], there should be order and safety. When it is not visible, armies must rise. ${ }^{\prime 20}$ For a sympathetic audience of Ming aristocrats, Zhu Quan's autobiographical discourse, with its unusually intimate tone, must sound as convincing as it can be. ${ }^{21}$ But can we afford the luxury of accepting it at face value? We must assume full responsibility for the problem of authorship. ${ }^{22}$ As Terry Eagleton puts it, 'If the author is not exactly dead, a naive biographism is no longer in fashion. ${ }^{23}$ Although biography must play an important role in a renewed assessment of Zhu Quan's authorship, the very nature of the record should caution us against the consequences of naive biographisms and unwarranted psychologising. Zhu Quan's private states of mind and mystical experience may engender a slew of hypotheticals, but the same cannot be said about the materiality of his claims.

This contribution argues that, as a unique phenomenon in the history of Chinese modes of deification, ${ }^{24}$ Zhu Quan's apotheosis must be interpreted as a paratextual discourse on authorship. ${ }^{25}$ This discourse is posited according to the collectively tangible framework offered by print culture. ${ }^{26}$ The notion of materiality is therefore inherent to the problem of Zhu Quan's apotheosis. But what is materiality and how to examine the precise relationship between authorial discourse and the material media that enunciates it? Although materiality may involve the notion of physicality, ${ }^{27}$ the former is not exclusively defined by the latter. The materiality of Zhu Quan's apotheosis must be sought in its ritual underpinnings. In order to substantiate this claim, I divided this article into three sections.

20 老人見, 治安 ; 不見, 兵起 (Shiji, 300.454a).

21 On the late Ming reception of Zhu Quan's authorship, see Schachter 2018b.

22 On this issue, see Burke 2008: 1-18, in which the author addresses the issue with a focus on the Nazi reception of Nietzsche's works.

23 Eagleton 1996: 208.

24 The term 'apotheosis', of Greek origins, obviously has no direct counterpart in Ming dynasty texts. However, the investigation of deification processes has pride of place in Daoist studies. Deification practices and discourses compete against one another from the early imperial period onwards. Examples abound. Recent scholarly literature offers important remarks for a history of apotheosis in China in the longue durée. For an erudite discussion of the term 'Daoism' and its elaboration in polythetic terms, see Raz 2012: 1-37. Concerning the Han, see Puett 2002: 313-15. See also Puett 2010: 223-252; Campany 2009; Raz 2012: 38-90. Nickerson 1994: 41-66; Kleeman 1994b. On the Celestial Masters, see Kleeman 2016. For the Six Dynasties, see Strickmann 1981; Robinet 1984; Bokenkamp 2007. As far as the Sui-Tang period is concerned, see Steavu 2019. For the Song evidence, see Strickmann 1978: 331-54; Ebrey 2014: 131-158. For the Ming, see Berling 1998: 953-86; de Bruyn 2000: 594-622; Wang 2012; Meulenbeld 2015: 98-167. Finally, the Qing evidence shows that apotheosis was not limited to humans; during spirit-writing sessions, certain instruments could become divine and acquire ritual agency. For a contemporary example, see Sutton 2003. I must thank Hu Jiechen for alerting me to the Qing evidence.

25 On the problem of authorship as a scholarly category, see Burke 2003; Beecroft 2010; Berensmeyer, Buelens, and Demoor 2019. On the problem of authorship as it applies to Sinology, see Fischer 2008-2009: 1-43.

26 On the history of pre-Ming print culture, see Barrett 2001 and 2008. According to Schipper (2004: 28) the first printed Daoist Canon appears under the reign of emperor Huizong (r. 1120-1126), during the Song. This is relatively late, if compared with the Buddhist evidence.

27 See Clunas 2013: 71: 'Only recently have scholars begun to consider them as objects worthy of our attention in their own right, and to consider their materiality and processes of production, alongside the knotty theoretical issues they raise regarding questions of authenticity and reproduction within Chinese culture.' Another potential source of scholarly inspiration is Hegel 1998, whose approach to illustrated culture also addresses the issue of materiality. Also, see Miller 2005. 
The first section describes the extant editions ${ }^{28}$ of the Pivot. This discussion is necessary for two reasons. First, the two extant editions are posthumous objects fabricated by later compilers after Zhu Quan's death. Second, since they survive in varying states of preservation, I must compare both editions when examining key passages. The second section discusses the paratextual nature of Zhu Quan's authorship. Relying on textual evidence, I propose an approximate date for Zhu Quan's lost edition of the Pivot. The main goal of this section, however, is to examine the performative nature of the book's preface. Investigating its rhetorical strategies in the light of certain sociohistorical factors, I explain how the preface constructs Zhu Quan's authorship as a divine author. The third section explores the ritual dimension of Zhu Quan's divine authorship. Relying on archaeological inscriptions, historical records, and Daoist scriptures, I explore the relationship between the king's divine title and Daoist theology. This is followed by a discussion of the Pivot's last chapter, the calendar of which presents Zhu Quan as one of its gods. I discuss in detail the calendar's ritual context and its intended audience. In a dialogue with the field of ritual studies, I explain to what degree Zhu Quan's calendar may be interpreted as an act of ritual textualisation.

\section{A BRIEF DESCRIPTION OF EXTANT EDITIONS}

The Pivot is a work devoted to agriculture, geomancy, and esoterica (see table 1). As expected, the book ignores the modern separation of religion, ${ }^{29}$ science, ${ }^{30}$ medicine, ${ }^{31}$ and aesthetics. ${ }^{32}$ The book survives in two editions, both stored in the National Library of China 中國國家圖書館, Beijing. I refer to them as E1 and E2. These two editions comprise transmitted texts based on earlier editions. ${ }^{33}$ The degree to which extant editions reproduce the content of lost editions, however, is difficult to determine. E1 is the earliest known physical edition attributed to the Perfected Lord. It constitutes, therefore, the most reliable evidence for textual comparison with later editions of books attributed to the divine king.

\subsection{On the term Zhouhou}

The compound zhouhou 肘後, in Zhouhou shenshu, is closely connected to the physical aspect of books. The character zhou 肘 occurs as early as the Huangdi neijing 黃帝内經 ${ }^{34}$ and points to a Chinese anatomical concept. Zhouhou means the 'rear side of the elbows', a pre-biomedical

${ }^{28}$ On Chinese manuscript culture, see Drège 1991. The production and transmission of printed editions is a matter of primary interest for historians and philologists, who approach books from the perspective of material culture. For studies of the Chinese book in the late imperial period, see McDermott 2006; Ming and Pierson 2006. Also, see Wang 2012: 61-82.

${ }^{29}$ On the creation of 'religion' as a modern Chinese category, see Goossaert and Palmer 2011.

30 Shen 2014: 91-137.

31 Karchmer and Scheid 2014: 141-194.

32 Davis 2014: 197-257.

33 See Schachter 2018a: 27-74.

34 The terms zhouhou, zhouzhong 肘中, zhouwai 肘外, and zhounei 肘內 occur in many passages of the Numinous Pivot (Lingshu 靈樞; Unschuld 2016: 239-245 and 501-509): 'When only the front of the elbows is hot, heat is present in the front of the chest. When only the rear side of the elbows is hot, heat is present in the shoulders and the back.' See Unschuld 2016: 669-677. The temperature of the zhou may play a determinant role in examination 
concept devoted to notions of how qi circulates in the human body. Applied to book titles, the term zhouhou points to easily transportable books. The long sleeves of a person's garments could hide elixirs, ${ }^{35}$ fragrant bags, ${ }^{36}$ talismans, and even small-sized books. The latter could be attached to the rear side of the carrier's elbow. ${ }^{37}$ When applied to book titles, therefore, the term zhouhou is roughly equivalent to the Latin expression vade mecum ('go with me'), which denotes a book sufficiently small to be carried about by a person in his pocket. In Chinese print culture, however, some authors explicitly adopt the term zhouhou with reference to content, not size. These editions are 'ready to hand' because content is presented in a condensed, useful, and easily consultable manner, not because they are easy to transport. This sense of the term zhouhou also applies to the Pivot, whose physical structure I explore below.

\section{$2.2 \mathrm{E} 1$ and its features}

The Book Catalogue of the Hall of Precious Writs (Baowentang shumu 寶文堂書目), produced during the Jiajing reign (1522-1566), mentions the Pivot. This catalogue, however, does not refer to the Pivot as a Ning Prefecture (Ningfu ke 寧府刻) edition..$^{8}$ In fact, E1 mentions a certain Book Hall of Abundant Joy (Yuqing Shutang 餘慶書堂), ${ }^{39}$ not the Wenying Guan 文英館 (the Ning Prefecture's printing house). According to paratextual elements, E1 dates back to the fourth lunar month (mengxia孟夏) of Chenghua 8 (1472), which is clearly indicated in vol. 1: 'newly printed at the Book Hall of Abundant Joy in the fourth lunar month of Chenghua renchen' (fig. 1). By this time, artisan households had achieved a certain degree of independence from state control (McDermott 2006: 33). The term 'newly printed' (xinkan 新刊) ${ }^{40}$ means two important things. First, E1 is not the first edition of the Pivot. Second, E1 is not a fankeben 翻刻本, i.e., its layout and physical features must differ considerably from its (now lost) source-edition. Produced twenty-four years after Zhu Quan's death, some of its pages show a poor state of conservation. A paratext seen in the first fascicle of the Chenghua edition demonstrates that E1 is an edited text: 'Master Lingyi recorded [靈嶧子記]' the Pivot (fig. 2). However, only the discovery of new materials may shed new light on the identity of this otherwise unknown Master Lingyi. Hu Kui 胡奎 (fl. Zhengtong) ${ }^{41}$

(zhen 診) methods. In this text, the 'elbow' is a 'bone' ( $g u$ 骨): 'The distance from the shoulder to the elbow is 1 chi 7 inches.' But this 'bone' is a reservoir of $q i$ vessels: 'The root of the hand yang brilliance [conduit] is located above the elbow bones where the [hand] yang [brilliance network] branches off.'

${ }^{35}$ DZ 885, 19:24b. On this early medieval alchemical text, see Pregadio 2006: 54-55.

${ }^{36}$ Yuefu shi ji 樂府詩集 76:7b.

${ }^{37}$ We also know that bags made of brocade were 'used to hold manuscripts for poetry in ancient times.' See the entry on jinnang 錦囊 in Zhang 2003: 1579 (entry no. 6427).

38 Baowentang shumu, 71.

39 This Yuqing Shutang may be the Fujianese printing house of same name. On this printing house, see Inoue 2006: 46-72. More evidence is needed, however, in order to prove this hypothesis.

${ }_{40}$ As can be seen in fig. 2, E1 uses a variant character (yitizi 異體字) for kan 刊.

${ }^{41}$ According to Ming-Qing sources, Hu Kui was a person from Haining 海寧, Zhejiang 浙江. He was born during the Zhishun reign (1264-1294) of the Yuan dynasty and became the instructor (jiaoshou 教授) of the Ning kingdom during Zhu Quan's time. 


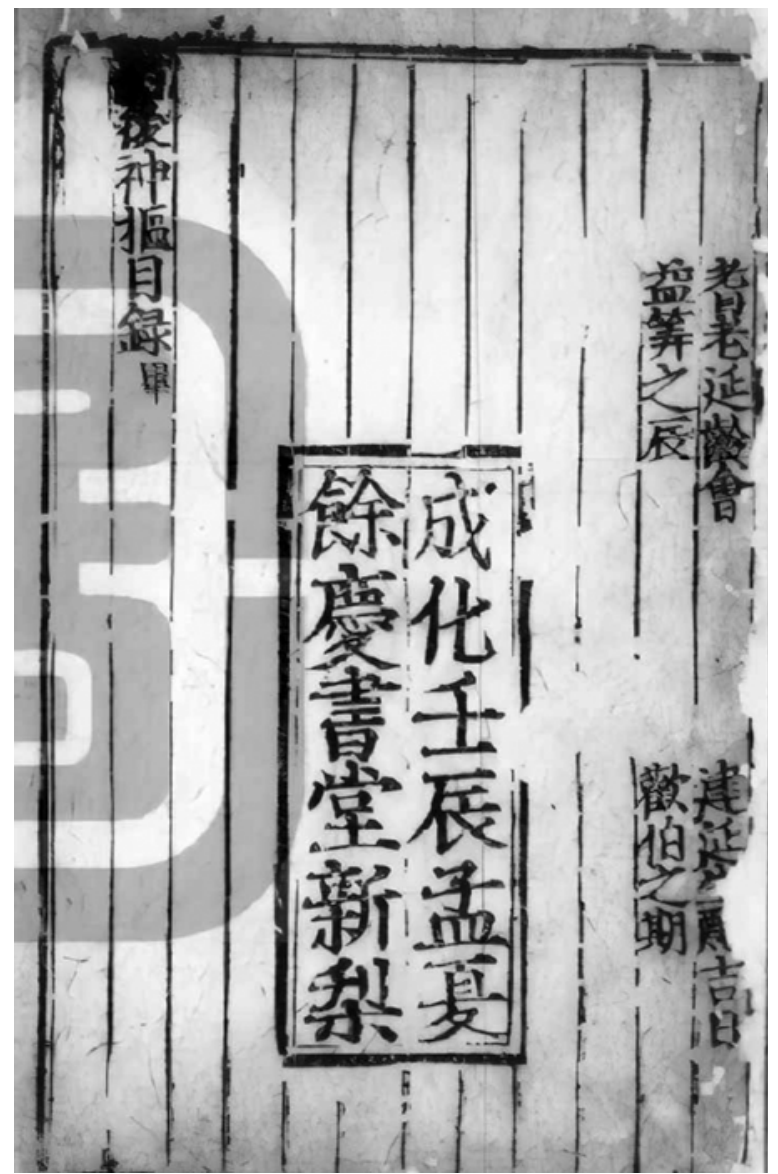

Fig. 1 - Paratext Showing E1's Date and Place of Fabrication.

may have played an important role in the process of the Pivot's textual transmission. ${ }^{42}$ His Poetical Anthology of Master Dounan (Dounan xiansheng shiji 斗南先生詩集), which bears a preface attributed to Zhu Quan, offers a significant and yet inconclusive clue. This anthology preserves a celebratory poem composed in homage of a certain Hall of Abundant Joy (Yuqing Tang 餘慶堂), whose geographical location the poem unfortunately does not disclose.

${ }^{42}$ Dounan laoren ji, 1a-3a. This poetic anthology survives in Qing printed edition and as a manuscript edition of possible Ming provenance. These editions record the name Wenying Guan, which refers to the Ning prefecture's printing house. However, the manuscript edition stored in the National Library of China cannot be Zhu Quan's lost edition of the early Ming. According to Zhu Quan's preface: 人皆稱之為詩仙, 信不誣矣。故命 壽諸梓, 以傳無窮焉。涵虛子臞仙書 'People call him [i.e., Hu Kui] the Immortal Poet; I think this is not absurd at all. I therefore had the printing blocks prepared, in order to transmit [his book] forever; written by the Master Embracing the Void [Hanxuzi 涵虛子], the Emaciated Immortal [Quxian 臞仙]' (Dounan laoren ji, 7a). The Wenying Guan edition of Hu Kui's anthology was a printed edition, not a manuscript. All this is evidence, nevertheless, that Hu Kui may be connected to the Yuqing Shutang mentioned in E1. 


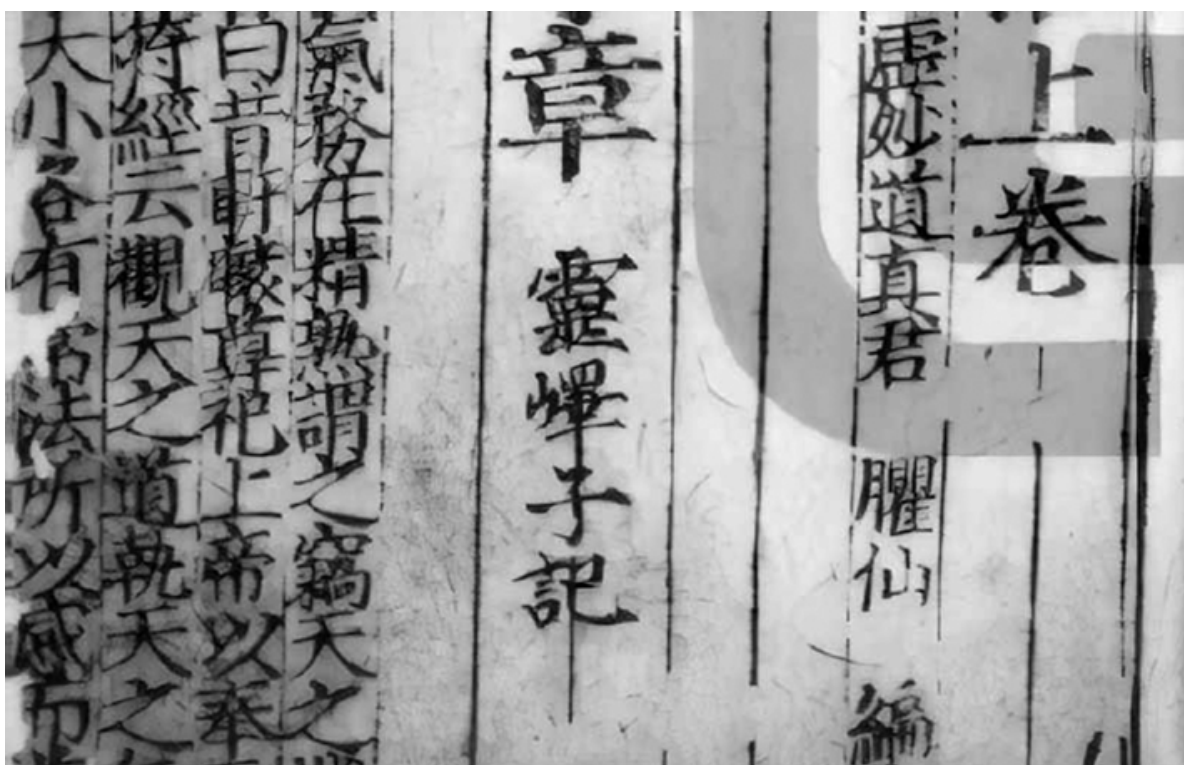

Fig. 2 - Paratext Recording Lingyizi's 靈嶧子 Editorship of E1.

\section{$2.3 \mathrm{E} 2$ and its features}

E2 provides no paratexts indicating the name of its printing house or its date of printing, nor does it provide information on its editors. However, this edition preserves the following stamp: 'Book from the collection of the Wus, from Haifeng' (Haifeng Wushi cangshu 海豐吳氏藏書). The Wus were actively involved in the Qing book market (Han and Sun 2013), especially in the area that corresponds to modern day Shandong. The Book Catalogue of the Wus, from Haifeng (Haifeng Wushi cangshu mu 海豐吳氏藏書目), which survives in Qing manuscript edition, records more than 1500 titles. ${ }^{43}$ This catalogue mentions both traditional Chinese books and Chinese translations of Western books on law and technology, thus reflecting the Self-Strengthening background in which it was created. This document, which is actually a sales record, proves that the Wus collected many editions of Daoist books, including multiple copies of the same titles. For example, the Wus owned 34 copies of the Twelve Genres of Daoist Books (Daoshu shier zhong 道 書十二種) ${ }^{44}$ It is not strange, therefore, to find a lost copy of the Pivot among the Wus' collection. Although it is not possible to know where E2 was produced, it is reasonable to presume its circulation in Qing-era Shandong. This edition is closely connected to the late imperial book market.

${ }^{43}$ Haifeng wushi cangshu $\mathrm{mu}, 56 \mathrm{a}$.

${ }^{44}$ Haifeng wushi cangshu mu, $3 \mathrm{~b}$. 


\subsection{Comparing E1 and E2}

E1 and E2 did not directly result from Zhu Quan's efforts. Both editions are thread-bound (xianzhuang 線裝) objects; they offer a summary, a grid system, and a convenient pagination system. These elements are not inconsequential. Heijdra (2006: 21) argues that the grid originates 'from a desire to regularise the page as a whole, to make the page of a more even colouring; and to actually guard against the concurrent economic impulse of ever increasing the number of characters per line.' The grid also increases readability, which only reinforces that our editions were designed as reading objects. E1 has double margins in all four corners (sizhou shuangbian 四周隻邊), with a thick black border (daheikou 大黑 $\square$ ), and black fishtail (hei yuwei 黑魚尾). E2 has a very similar layout, but other aspects, such as size, typographic elements etc. differ considerably.

Book producers paid great attention to the physical and aesthetic aspects of editions, which were very relevant for Ming-Qing audiences. ${ }^{45}$ E1's preface, for example, suggests a skilled calligrapher behind it, instead of a mere transcriber, which seems to be E2's case. ${ }^{46}$ Without a doubt, E1 wants to convey the impression that it reproduces Zhu Quan's calligraphy. It does so in an aesthetically compelling manner. The aesthetic conventions informing E1, therefore, must have contributed to increase its perceived cultural value, independent of whether this edition was produced for insertion in the book market or not. The plain text of E1 is distributed in 12 lines per page, each line comprising a maximum of 23 characters. In E2, the plain text occupies 13 lines per page, with 24 characters per line. The plain text of E1 adopts larger characters of quasi-rectangular shape. E2, on the other hand, was carved in box-shaped characters ${ }^{47}$ that obviously allowed the publisher to squeeze more characters onto the surface of a woodblock. ${ }^{38}$ This typographic feature became common during the late Ming. Therefore, E2 must be later than E1, even if we do not know its precise fabrication date. The typographical discrepancy between E1 and E2 explains why the former comprises three fascicles while the latter, following a more economical arrangement, requires only two separate fascicles.

Judging from its general features, E2 must correspond to a less expensive edition. It nevertheless provides interesting evidence concerning the history of reading in late imperial China. The top margins of certain pages record handwritten annotations. ${ }^{49}$ The previous owner of E2 copied the contents of other books over the surface of this edition. The copied contents concern esoteric lore seen in Qing editions. ${ }^{50}$ Evidently, its owner was someone highly interested in comparing esoteric books.

${ }_{45}$ Among these reasons, one should mention the culture of book gift and the book market. See McDermott 2006: $83-114$.

46 This is in accordance with McDermott 2006: 26, 'Whereas up to the early Ming the transcriber of a literati text onto the paper sheets destined for a woodblock might be the author of the text, his disciples, his friend, his son, or even a respected calligrapher, from the latter half of the Ming the transcriber even for literati works was normally a 'mere transcriber."

${ }^{47}$ E1 seemingly adopts the so-called Songtizi 宋體字, while E2 adopts the Mingchao ti 明朝體. On the terms Songtizi and Mingchao ti, see Heijdra 2006: 15-27.

48 McDermott 2006: 28. It is important to notice, however, that McDermott names these box-shaped characters as Songtizi, which in Heijdra's terminology would correspond to Mingchaoti. In the Sinosphere there is no agreement about the terminology. See Heijdra 2006: 19.

$49 \mathrm{E} 2,2.67 \mathrm{~b}-70 \mathrm{~b}$.

50 See E2, 2.70a; this page records the contents of a certain Jibing sisheng pian 疾病死生篇. These handwritten annotations roughly conflate with the contents of the Guanli huizhan, 11.252. 
The above demonstrates that the Pivot's provenance is, to say the least, obscure. We will probably never know the details of its pre-Chenghua editorial history. We know, however, that as early as Chenghua 3 (1467) courtly historians recorded Zhu Quan's authorial activities for the first time. ${ }^{51}$ The fact that our editions cannot be traced back to the Ning prefecture is very significant. It demonstrates that private initiative was as important in the preservation of Zhu Quan's oeuvre as kingly and imperially sponsored editions. Unlike later editions of Zhu Quan's works, E1 does not contain paratexts authenticating the king's authorship. If anything, this absence suggests that the editors behind this edition did not feel compelled to argue for its authenticity. This may indicate a connection between this edition and Zhu Quan's most immediate circles. In fact, Zhu Quan's sons and daughters, some of whom were married to people of lesser social station, may have played an important role in the dissemination of his oeuvre outside imperial circles. ${ }^{52}$

E1 and E2 share the same redaction. It is safe to assume, therefore, that E2 descends from E1, even if in an indirect manner. Only E2 preserves Zhu Quan's preface in its entirety. The fragment of preface seen in E1, whose first pages are missing, is identical to the last page of the preface as recorded in E2. We are on good grounds to suppose that E2 provides access to the lost text of E1's preface. In the following section, I examine how the preface constructs Zhu Quan's authorship.

\section{PARATEXTUAL PERFORMANCE: THE PIVOT'S PREFACE}

The Preface to the Pivot (Zhouhou shenshu xu 肘後神樞序) reads:

予嘗體道探玄, 蒐獵蘊祕, 稽古考文而鉤深索隱者, 四十餘年矣。其天文、地 理、人事之驗, 靡不留心, 而所知所得者, 錄甚精微, 以備幽討, 乃有肘後之神 樞作焉, 而神機鬼藏之旨悉備陳於是書矣。然其紫極瓊臺之典, 琅函玉篖之書, 奇門神盾之奧， ○古云 0000000000 者若 00 之 0 輝其光猶在,實希世 之寶, 天地 $\bigcirc 之$ 文, 若繁風鏤影, 孰能操之? 乃知開滅之嚴峻也。予恐泯而無 傳, 於是輯為三卷。上以宣天道之化。中以彰神明之德。下以括地利之貞。分為 十一章, 條陳一百一十九事。其上卷止存風雨、陰晴之占。凡觀象占休各者, 悉 刪之。其中卷內篇乃神盾天奇之祕, 勿敢輕泄, 以謹天戒也, 附之別錄。盍是 書者, 妙有不言之祕, ○無再造之功, 是謂奪天巧而蝺造化, 可以透天關而對鬼 窮, 乃跧鬼窮以通天關, 握神樞以符造化, 其機也, 陰陽不能神, 鬼神不能隱, 造化於斯, 拙於我矣。《陰符經》日：觀天之道, 執天之行, 盡矣。宇宙在乎 手，萬化生乎身。八卦、甲子、神機、鬼藏、陰陽相勝之術昭昭乎盡乎象矣。非 人勿視, 非人勿傳, 得之者當珍○而藏焉。前南極沖虛妙道真君臞仙書。5 3

More than forty years have passed since I commenced to embody the Path ${ }^{54}$ and scrutinise its mysteries, collect and search for its abstruse secrets, investigate antiquity and examine texts, thus linking up what is profound and searching out what is hidden. ${ }^{55}$ When it comes to the manifestations of the celestial patterns, terrestrial principles and human affairs, there

51 Veritable Records/Yingzong/170.3280. Historians did not mention the Pivot.

52 Some of Zhu Quan's daughters were married to commoners. See Schachter 2019a: 132-37.

53 E2, 1.1a-2b.

54 體道. E2, 1.1a. This is an obvious reference to Zhuangzi's parlance. On the importance of Zhuangzi for Ming Daoists, see Meulenbeld 2016: 35-91.

55 鉤深索隱. E2, 1.1a. The locus classicus of this sentence seems to be the book Zhouyi 周易, 65.11a. 
is not a single [event] that would carelessly escape my attention. As for what I was able to know and achieve, I recorded it in an extremely detailed and minute manner, so as to prepare for profound incursions; ${ }^{.6}$ and then I created the Divine Pivot Ready to Hand, recording and presenting all the purposes of the divine mechanism and of the demonic repositor $y^{57}$ in this book. [This work] is like the classics found in the gem-made terraces of the Purple Pole ${ }^{58}$ or the books stored in cases made of jade and boxes made of precious stones, ${ }^{59}$ the mysteries of the wondrous gates and the divine hidden [days] ${ }^{60} \bigcirc^{61}$ The ancients said: $\bigcirc^{62}$ Who could grasp it? Only then would one know how strict and steep are [the ways of] creation and extinction. [The thought of this book] vanishing and therefore not being transmitted anymore left me aghast, which is why I edited it in three scrolls. The first [scroll] promulgates the transformations of the Celestial Path. ${ }^{63}$ The second [scroll] gives distinction to the Virtue of the divinely bright ones. ${ }^{64}$ The last [scroll] summarises the righteousness of the terrestrial advantages.$^{65}$ I divided it into eleven chapters, which I display in 119 articles. The first scroll records only the prognostications related to wind, rain, cloudy and clear weather. As for the contemplation of the hexagrams and the prognostications for what is auspicious and inauspicious, they were all excluded. The internal chapters of the second scroll are about the secrets of the divine hidden [days] and celestial wonders. I do not dare to lightly divulge [the second scroll] and, in careful compliance with the celestial admonitions, I have placed it [elsewhere] and did not record it. For this book wonderfully conveys the unspeakable secrets and the $\bigcirc$ merits of renewed creation; ${ }^{66}$ this is called to usurp the celestial artfulness and to steal from the creation-transformation. [You will] be able to invade the celestial gates and drill the demonic orifice; then [you] will drill the demonic orifice in order to penetrate the celestial gates. [You will] grasp the divine

56 Profound incursions (youtao 幽討) is a common topos in Chinese poetry.

57 The divine mechanism (shenji 神機) and the demonic repository (guizang 鬼藏) are key concepts of the Yinfujing 陰符經. I discuss this issue below.

58 In Daoist scriptures, the terms Purple Pole ( $z i j i$ 紫極) and gem-made terrace (qiongtai 傻臺) are toponyms; they may refer to several spiritual palaces. Zhu Quan mentions the notion of Purple Pole in the preface of his Jade Slips, 1b: 'and grasp the Divine Pivot at the Purple Pole' 握神樞於紫極. Clearly, there is a thematic connection between both prefaces.

59 This is a common literary topos. See Jade Slips, 38a.

${ }^{60}$ The wondrous gates and the divine hidden [days] (qimen shendun 奇門神盾) refers to qimen dunjia 奇門遁甲 lore, which I discuss below.

61 The sentence is interrupted here by a lacking character.

62 The preface lacks a total of 18 characters. Of these, 15 unidentifiable characters occur in this sentence attributed to the ancients, which therefore became illegible: 古云 $\bigcirc 0 \bigcirc 0 \bigcirc \bigcirc \bigcirc \bigcirc \bigcirc \bigcirc$ 者若 $\bigcirc$ 之 0 輝其光猶 在,實希世之寶, 天地 $\bigcirc 之$ 文, 若繁風鏤影, 孰能操之? I chose to translate only the last sentence of this quotation.

${ }_{63}$ The notion of promulgating the Celestial Path also occurs in the Jade Slips, $4 \mathrm{~b}$.

${ }^{64}$ In other words, the gods, or shenming 神明.

65 The notion of terrestrial advantages (dili 地利) occurs in many pre-Qin texts, including the Liji 禮記 and the $M e n g z i$ 孟子. Its meaning may vary according to context, but there should be no doubt that it has an important role in texts about war and strategy.

66 The text lacks one character before the expression zaizao zhi gong 再造之功, which I translate as 'the merits of renewed creation' The term zaizao occurs in many chengyu 成語, while the expression zaizao zhi gong has a positive connotation in many late imperial texts. 
pivot in order to correspond ${ }^{67}$ to the creation-transformation. [Due to] its mechanism, yin and yang will cease to be divine; the demons and gods will not be able to hide themselves. At this [point], creation-transformation will be clumsier than us. ${ }^{68}$ The Scripture of the Hidden Correspondence says: 'Contemplate the Path of Heaven and execute the Movement of Heaven: this is completeness. The universe is in one's own hands; the ten thousand transformations are born in one's own body. The eight trigrams, the sexagenary cycle, the divine mechanism, the demonic repository, and the art of mutual conquest of yin and yang shall shine brightly in complete visibility. You must not show it to non-initiates. You must not transmit it to non-initiates. Those who obtain it should cherish ${ }^{69}$ and conceal it. The above was written by the Emaciated Immortal, the Perfected Lord of the Wondrous Path of the Unfathomable Void from the Southern Pole.

The preface translated above defines the Pivot as a 'book' (shu 書) and Zhu Quan as a divine author. Corroborating his divinity, the king shows himself a demanding and sophisticated author. Instead of offering an unequivocal date of composition, the paratext establishes historical verisimilitude through more subtle rhetorical strategies. The divine Zhu Quan, simultaneously philosopher and philologist, offers a glorious narrative about his scholarly activities. In claiming that the Emaciated Immortal investigated the secrets of antiquity for 'more than 40 years', ${ }^{70}$ the paratext follows autobiographical conventions, presenting the Pivot as a work of erudite scholarship. The date of composition is a riddle that must be solved by means of a comparison between text and paratext. Elsewhere, the book mentions the title Inheriting Authority through the Celestial Revolutions (Tianyun shaotong 天運紹統). This is also an implicit, less obvious, autobiographical reference. ${ }^{71}$ The same passage mentions the reign name 'Zhengtong. ${ }^{72}$ For this reason, the Pivot cannot be earlier than 1435. External sources are equally helpful. The Jade Slips, finished in 1444, mentions the book title Pivot. ${ }^{73}$ Therefore, the former provides a terminus ante quem for the latter. The compilation of the Pivot's first edition, now lost, must have occurred between the years 1435-1444, when Zhu Quan was stationed in Nanchang. By this time, the Ming king was heading to advanced age. This hypothesis agrees with the preface.

Apart from establishing an autobiographical narrative, the preface is a discourse on the relationship between text and society. In the preface, the Perfected Lord presents the Pivot as a book concerning the celestial patterns (tianwen 天文), the terrestrial principles (dili 地理), and the human affairs (renshi 人事). ${ }^{74}$ The same preface claims that the Pivot reveals the mysteries

${ }^{67}$ Here, the character $f u$ 符 works as a verb. I am aware that, in other contexts (including the book title Yinfu jing) it may point to objects such as talismans and contracts. Given the semantic richness of the term, I chose to translate $f u$ as correspondence (noun) and to correspond (verb), thus emulating the Chinese syntactic symmetry.

68 The sentence zaohua yu si zhuo yu wo yi 造化於斯拙於我矣 imposes significant difficulties to the translator. I translate wo 我 as 'us', not 'I' nor 'me', because this sentence is not about Zhu Quan or any specific person. The sentence addresses the implied reader who, in possession of the Pivot's teachings, will transcend the limits imposed by zaohua, or the creation-transformation.

${ }^{69}$ In E2, the compound for 'cherish' is corrupted, since it lacks the second character, reading zhen $\bigcirc$ 珍 $\bigcirc$. E1 offers the compound zhenxi 珍襲.

70 四十餘年矣. E2, 1.1a. The corresponding page is lacking from E1.

${ }^{71} \mathrm{E} 1,1.45 \mathrm{~b} / \mathrm{E} 2,1.46 \mathrm{~b}$. Zhu Quan compiled the Tianyun shaotong during the Yongle period, after he was reinvested in Nanchang 南昌.

${ }^{72} \mathrm{E} 1,1.45 \mathrm{~b} / \mathrm{E} 2,1.46 \mathrm{~b}$.

73 Jade Slips, 37b.

${ }^{74}$ E2, 1.1a. The corresponding page is lacking from E1. 
of qimen shendun ${ }^{75}$ also known to modern adepts as qimen dunjia 奇門遁甲. ${ }^{76}$ The Jade Slips corroborates Zhu Quan's connection with qimen lore. ${ }^{77}$ Needless to say, the fabrication of calendrical almanacs has an important place in Chinese culture since high antiquity ${ }^{78}$ During the early Ming, Zhu Yuanzhang saw the creation of official calendars, the Datong li 大統曆, as an essential element of governance strategies. Not by coincidence, the Pivot presents tables that agree with the rationale of the Datong $l i{ }^{79}$ The Ming founder also used such calendars as an effective diplomatic tool. ${ }^{80}$ Zhu Quan's involvement with calendrical compilations seems to be modeled upon his father's keen interest calendars. The king's creation of calendrical books undermines the argument according to which Ming kings, from the Yongle period onwards, were completely isolated from political life. If calendars and almanacs were a matter of governmental and even diplomatic importance, their compilation was something akin to political influence. In creating calendars, the king established some degree of political authority for himself.

The preface is also a discourse about the relationship between text, support, and intended audience. The paratext explicitly mentions the Scripture of the Hidden Correspondence (Yinfu jing 陰符經) ${ }^{81}$ In a sense, the preface presents the Pivot as a Ming recreation of the Yinfu jing. Accordingly, its transgressive terminology, reminiscent of yinfu lore, ${ }^{82}$ promises that the reader, who is a

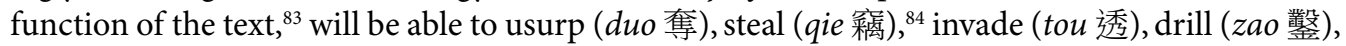
and penetrate (tong 通) the celestial secrets. The Perfected Lord promises to lay out the invisible principles informing the divine mechanism (shenji 神機) ${ }^{85}$ Those who master such principles, or 'grasp the divine pivot' (wo shenshu 握神樞), will obtain control over the modus operandi of the creation-transformation ( $z a o h u a$ 造化), so that 'yin and yang will cease to be divine; the demons and gods will not be able to hide themselves. The Pivot is a book about power and control: 'those who obtain it should cherish and conceal it', for secrecy is power. But this discourse involves a significant tension between publicity and secrecy.

75 奇門神盾之奧. E2, 1.1a. E1 also lacks this page.

${ }^{76}$ On this term, see Ho 2003.

77 This book mentions the Secret scripture with the methods for the fabrication of dunjia cosmic boards of the six hidden days and the three principles (Liujia sanyuan dunjia zaoshi mijing 六甲三元遁甲造式秘經). See Jade Slips, 219a. Zhu Quan did not invent this scriptural title; it also appears in Daoist sources, according to which 'on 29/07 of Shanghuang 3, in a renzi day, Tianzhen Huangren 天眞皇人 descended and conferred upon the Yellow Thearch the diagrams for the cosmic board of the Six Ren [Liuren shitu 六王式圖], and the methods for the fabrication of dunjia cosmic boards of the six hidden days and the three principles [Liujia sanyuan dunjia zaoshi zhi fa 六甲三元遁甲造式之法]. These methods serve the fabrication of 'cosmic boards. The instrument named $s h i$ 式 precedes the Han period. See Harper 1978: 1-10; Kalinowski 2013: 331-60.

78 For a discussion of excavated materials, see Kalinowski 2008: 1-48.

79 As early as 1367 , Zhu Yuanzhang had perceived the import of establishing calendars as the foundation (ben 1 - $)$ by means of which 'kings and emperors pay respect to heaven and serve the people.' See the Taizu baoxun, 6.446.

${ }^{80}$ For historical records concerning the distribution of calendars to foreign embassies, including Japan, present day Indonesia, Vietnam, and Korea, see Veritable Records/Taizu/39.786; 43.847-848; 44.867.

81 For a translation, see Acker 2006.

${ }^{82}$ Much work remains to be done on the Yinfu jing's editions and the circumstances of its transmission during the late imperial period. On the many commentaries and traditions created around the Yinfu jing, see Schipper 2004: 319-23 and 691-701.

${ }^{83}$ On the text-reader relationship, see Castle 2007: 173-180.

84 This sort of conceptual framework also occurs in neidan texts, see Robinet 2008: 1214.

85 The notion of mechanism, or $j i$ 機, has a long history and appears in many pre-Qin texts. In these texts, $j i$ occurs both in the literal sense of machine and in the sense of modus operandi, or process, to mention some of its usages. 
The preface represents a clever solution for this tension. Adopting terms such as scroll (juan 卷), chapter (pian 篇), and edit/compile ( $j i$ 輯), it describes the book's physicality in a way that is reminiscent of manuscript culture; this rhetorical operation implies a juxtaposition between old and new, between esoteric manuscripts and printed texts produced for circulation among non-initiates. But other paratexts of the Pivot demonstrate that Zhu Quan's first edition was a printed work, not a manuscript. The summary of E1, for example, shows that this particular edition derived from a lost printed edition, for its 'second scroll' (juanzhong 卷中) 'was not transmitted because it was never printed.86 According to the preface, in its 'original' configuration the Pivot comprised eleven chapters distributed into three juan 卷. However, the deified Zhu Quan never had the second juan printed; he did not want to reveal the celestial secrets in their entirety. The extant Pivot, therefore, comprises only nine chapters. In both editions, the summary endorses the preface. ${ }^{87}$ These two paratexts negotiate degrees of accessibility to the esoteric realm. The preface constitutes a strategy for the preservation of esoteric authority in a period when traditional Daoist lineages must coexist with new modes of textual transmission, including commercial presses and spirit-writing altars, whose existence Zhu Quan explicitly acknowledges in his Jade Slips. ${ }^{88}$ The preface safeguards the interests of ritual specialists and masters of esoterica (i.e., those who make a living from secret knowledge). But it presents this esoteric discretion as resulting from the Perfected Lord's deliberation. In other words, the rhetoric of secrecy as power is a claim about Zhu Quan. It reinforces Zhu Quan's status as a divine source of reliable knowledge. The Pivot, the Jade Slips, and the archaeological record corroborate this hypothesis, which I explore in the next section.

\section{THE RITUAL UNDERPINNINGS OF ZHU QUAN'S DIVINE AUTHORSHIP}

Nowhere does the Pivot mention the name 'Zhu Quan'. The preface, for example, describes the king as the Perfected Lord (see fig. 3). This paratext is, fundamentally, a discourse about divine authorship. In signing his preface as the Perfected Lord of the Southern Pole, Zhu Quan advanced an interesting claim about personhood. The term 'Southern Pole' (Nanji 南極) has a long history; it predates the Ming king and informs his identity as a Daoist god. References to this notion abound in Zhu Quan's oeuvre. Its presence in his divine title, therefore, was not a random choice. His persona as the Perfected Lord must be understood as a new development that takes place in the context of a long tradition.

86 不刊故無傳. E1, 1.3a.

87 The respective summaries of E1 and E2 are almost identical. Apart from typographical features and layout, a noticeable difference is that in E1 the summary has the complete title Zhouhou shenshu mulu 肘後神樞目錄, while in E2 it receives the abbreviated title Mulu 目錄.

${ }^{88}$ On pre-Ming spirit-writing, see Kleeman 1994a. The Jade Slips explicitly mentions spirit-writing practices in the 33 Levels of the Grand Methods of the Precious Register Communicating with Heaven (Tongtian baolu dafa sanshisan jie 通天寶籙大法三十三階), a list including: (1) jiangbi 降筆; (2) taiji luan 太極鸞; (3) bijia luan 筆架 鸞; (4) xuansi luan 懸絲鸞; (5) fengxia luan 封匣鸞. These five 'levels' (jie 階) are the last items of this list of 33 methods. This positioning in the list suggests that these five levels may be considered 'inferior' to the preceding ones. See Jade Slips, 89b. 


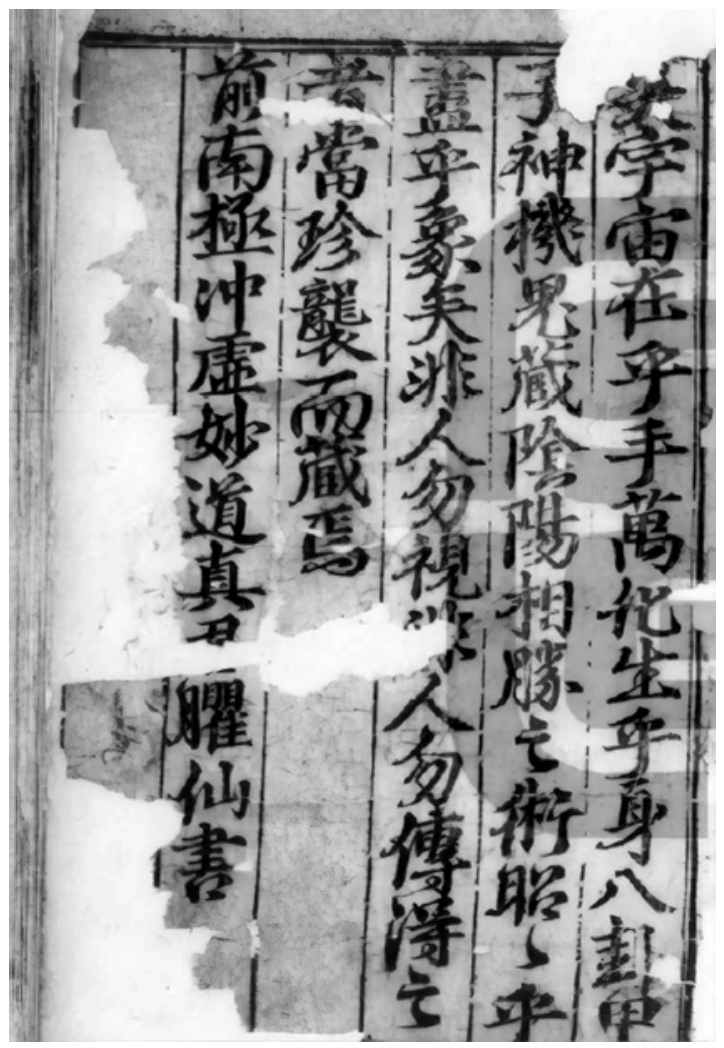

Fig. 3 - The Authorial Paratext Nanji Chongxu Miaodao Zhenjun in E1.

\subsection{Biography, Daoist theology, and the archaeological record}

The Veritable Records of the Ming dynasty (Ming shilu 明實錄) ${ }^{89}$ shows that the Zhengtong reign, when Zhu Quan compiled the Pivot, was a tumultuous and yet prolific period for the Ming king. Between 1436 and 1442, amidst dramatic political events at the Zhengtong court, Zhu Quan was extremely busy with his domestic affairs. ${ }^{90}$ The death of his eldest son Zhu Panshi 朱盤烒 ${ }^{91}$ must have constituted a personal tragedy for him. In the following year Zhu Quan commenced to handle his own obsequies.

${ }^{89}$ For scholarly discussions of Ming sources, see Franke 2011. In the footnotes below, I refer to the Ming shilu edition prepared by the Academia Sinica for the Hanji quanwen ziliaoku 漢籍全文資料庫(Scripta Sinica) database. Volume and page numbers follow this database.

90 These included the ritual appropriateness of his garments, marriage arrangements for his sons and daughters, and private benefits for his immense family. The king requested educational improvements (probably for his grandsons), labour exemption, increasing of emoluments, housing and healthcare as well. See Veritable Records/ Yingzong/22.448; 27.540; 39.750; 43.842; 47.916; 63.1200.

91 This took place on 01/19 of Zhengtong 2 (1437). See Jiangxi sheng bowuguan 2010, 15. 
On 02/05 of Zhengtong 3 (1438), he asked permission to construct his mausoleum, the Southern Pole's Palace for Prolonging Life (Nanji Changsheng Gong 南極長生宮). The Ming court ordered the Three Offices (sansi 三司) of Jiangxi to execute the project. ${ }^{92}$ On 09/25 of Zhengtong 7 (1442), Zhu Quan memorialised again, this time asking permission to consecrate the newly built Nanji Changsheng Gong, 'in order to worship the Perfected Man of the Southern Pole' (si Nanji zhenren 祀南極真人). He also asked that Daoist acolytes (daotong 道童) be installed at the Nanji Changsheng Gong. The Zhengtong emperor agreed, but he also made it clear that 'no exceptions would be conceded later. ${ }^{\text {'93 }}$

The god Nanji Zhenren, mentioned in the Veritable Records, is but one of the many anthropomorphic versions of Nanji. The Jade Slips mentions many pre-Ming manifestations of the Southern Pole, ${ }^{94}$ whose image as the god of longevity dates back to the Han period, ${ }^{95}$ when the god appears in 'materials that claim humans to have spirits within their body that, if properly cultivated, allow the adept to himself become more refined and to draw closer to the One' (Puett 2010: 226). In these texts, the Southern Pole's iconography differs considerably from late imperial representations, which show an old man of protruding forehead holding a peach in his hand. Han lore, however, will have a definite role in Daoist developments of the Southern Pole's image. Early Shangqing scriptures ${ }^{96}$ refer to a god named the Highest Perfected One from the Cinnabar Hill, the Old Man from the Southern Pole (Nanji Laoren Danling Shangzhen 南極老人丹陵上真). ${ }^{97}$ These texts connect the god to the Precious Instructions of the Jade Scripture (Yujing baojue 玉 經寶訣), ${ }^{98}$ ascribed to the Primordial Lady from the Southern Pole (Nanji Yuanjun 南極元君), a female manifestation of the Southern Pole. Those who practise her methods for 15 years will be welcomed by the Elders (Laoren 老人) of the five directions, including Nanji Laoren Danling Shangzhen. The term Nanji Zhenren, used by the redactors of the Veritable Records, appears in scriptures of the early Lingbao canon. ${ }^{99}$ The god inhabits the Dongyang Palace (Dongyang Gong 洞陽宮), which is the final destination of those who, cultivating Lingbao methods, have a karmic predestination to be reborn in the Daoist Heavens. ${ }^{100}$ The gods Nanji Changsheng Dadi 南極長

92 Veritable Records/Yingzong/39.750.

93 Veritable Records/Yingzong/96.1935.

94 These gods are: (1) Nanji Laoren 南極老人; (2) Nanji Weng 南極翁; (3) Nanji Zhuling Dantian Shangdi 南 極朱陵丹天上帝; (4) Nanji Changsheng Dadi 南極長生大帝; (5) Shouxing 壽星. Jade Slips, 32b, 184a, 24b, 223b, 220a.

95 According to DZ 1168 Taishang Laojun Zhongjing 太上老君中經, 'Nanji Laoren is the Lord of Niwan.' DZ 1168, 1.5a. On this text, see Lagerwey 2004: 139-71. This Han dynasty scripture explains the Lord of Niwan as 'the god of the brain' (nao shen 腦神). Schipper 2004: 92-94. The text describes Nanji Laoren as one of the deities residing in the head. His style ( $z i$ 字) is Yuanxian 元先/Yuanguang元光. The existence of Xian 先/Guang 光 as alternative names may reflect scribal errors. This text provides a peculiar iconography for Nanji Laoren: he dresses pearl-attires of five colours and measures nine fen 分. The adept must visualise ( $s i$ 思) him and, upon seeing (jian 見) the god, proffer the following incantation: 'Nanji Laoren confers upon [adept's name] a long life...' See DZ 1168, 1.5a. DZ 1168, 18.5b preserves the same passage.

96 The most relevant textual study of the Shangqing corpus to date is Zhang 2008.

97 The earliest mention of this god occurs in two early Shangqing scriptures: (1) DZ 405 and DZ 1377. Schipper 2004: 146.

98 DZ 405, 10a-12a. DZ 1377, 2a-4b.

99 Namely, DZ 22 and DZ 97.

100 These 'apprentices' (xueren 學人) of Lingbao lore, will enter (jin 進) the Dongyang Palace - the post-mortem relies on the same metaphors of the physical world, being its continuation - once they have undergone sublimation (lian 錬) in the Halls of Flowing Fire. Only then, under the condition of Perfected Ones (zhen 真), will they be able to approach Nanji Zhenren in his sacred residence in order to receive further sublimation. Accord- 
生大帝 and Zhuling Dadi 朱陵大帝, also mentioned by Zhu Quan in his Jade Slips, are closely associated with Song Daoist liturgies and Thunder Ritual. ${ }^{101}$ Daoist scriptures describe these pre-Ming deities as the original proponents of deification practices, sublimation processes, and longevity lore. Like these gods, the deified Zhu Quan is an anthropomorphic manifestation of the Southern Pole who reveals longevity teachings. However, there is an essential difference between the deified Zhu Quan and the aforementioned gods. These pre-Ming gods are closely associated with the creation of ritual lineages. ${ }^{102}$ The deified Zhu Quan is not such a god.

Corroborating the Veritable Records, inscriptions of 1442 construct his apotheosis as an event of national significance. As noticed by Clunas, the names of Zhu Quan's buildings, 'such as 'Palace of Eternal Life' (Chang sheng dian) and 'Palace of the Southern Pole Star' (Nan ji dian), have a powerful Daoist flavour. ${ }^{103}$ Indeed, the name Nanji Changsheng Gong derives from Daoist scriptures and also occurs in the archaeological record. The terms Nanji Gong 南極宮, Nanchang Gong 南昌宮, Nandou Changsheng Gong 南斗長生宮 etc. are variants of the same theological notion. The concept of a Southern Palace dedicated to longevity/sublimation has its origins in Shangqing and Lingbao texts (Bokenkamp 1997: 55-67). The name Nanji Changsheng Gong appears, verbatim, in a Celestial Master petition of the post-Tang period. ${ }^{104}$ In the corresponding ritual, a Daoist priest presents a human effigy (or 'metallic person', jinren 金人) to the Nanji Changsheng Gong in order to beg for the ill person so that her name 'may be relocated into the books of life and jade calendars.' ${ }^{105}$ According to this petition, the spiritual palace Nanji Changsheng Gong rules over human longevity. Inscriptions at the ruins of Zhu Quan's Nanji Changsheng Gong cohere with Daoist theological formulations of a Southern Palace devoted to the

ing to later commentators, such acts of sublimation are the prerogative of Nanji Zhenren: 南極真人則以火 膏洗錬, 蕩除塵垢, 得與真人為侶。'Nanji Zhenren uses the fire balm to wash, sublimate and purify [the Lingbao apprentices] from dust, [so that they] may become companions to the Perfected Men.' DZ 90, 5.10a. DZ 87, 4.11a. DZ 89, 4.8b. See Bokenkamp 2007: 35-36: 'There was the subterranean Yellow Springs, where commoners were believed to labor, as they had in life on the banks of the Yellow River, governed by those who had governed them before.'

${ }^{101}$ Changsheng Dadi and Zhuling Dadi are the deities in charge of the sacred sites for sublimation of the deceased. Their ritual role is akin to Nanji Zhenren's ritual performance. Changsheng Dadi is the head of the Nine Stars (jiuchen 九辰). This configuration of nine gods derives from Daoist liturgical formulations of the Song onwards. Some texts conflate Nanji Changsheng Dadi and Zhuling Dadi, describing them as the same god. The same texts work out a conflation of the Dongyang Gong, seen in Lingbao scriptures, with theological sacred sites for the sublimation of the deceased such as the Nanchang Gong 南昌宮 and the Zhuling Fu 朱陵府. The classical formulation of this cohort occurs in a Shenxiao scripture, DZ 15. On this text, see Schipper 2004: 1091; Skar 1997: 172. n. 22.

102 On early strategies of lineage creation, see Raz 2012: 38-90.

103 Clunas 2013: 54.

104 It appears in DZ 615 Chisongzi zhangli 赤松子章曆. On this text, see Verellen 2004: 291-343 and Verellen 2019 : 19-122. The aforementioned petition is named 'Golden-Purple Petition for the Replacement of [a Person's] Body on the Occasion of the Great Catastrophe of the Nine Diseases', or Jiubing da'e jinzi daixing zhang 九病 大厄金紫代形章. See DZ 615, 6.2b-9b. There is evidence that in DZ 615 the term Nanji Changsheng Gong occurs in the post-Six Dynasties portion of the Ming edition, which also mentions a sacred site named Nanji Nanchang Gong 南極南昌宮. See DZ 615, 6.6b. A petition of same title occurs in DZ 463, dated to the early 8th century, see Schipper 2004: 455-56. DZ 615 provides the complete text of the petition, while DZ 463 only mentions the tools, utensils, pledges and admonitions to be observed in relation to the usage of that device. The petition of DZ 615 addresses the problems of living people who are said to have contracted diseases due to their lack of virtue, which also reflects Daoist views of health and illness. DZ 615 and DZ 463 do not reflect the same redaction, version, or even the same ritual procedure.

105 更上生籍玉曆之中. DZ 615, 6.6b. 
longevity of the living and the sublimation of the deceased. His mausoleum corresponds to a cruciform structure comprising five different rooms. In front of its ruins there are two columns of $6.9 \mathrm{~m} \times 0.20 \mathrm{~m}$ each, ${ }^{106}$ on one of which we can read:

\section{皇明天曆正統染年歲在王戌拾蕒月拾陸日，南極沖虛妙道真君立，永鎮是宮，與 天地長存。107}

On 16/12 of Zhengtong 7 in the Celestial Calendar of the Resplendent Ming, the Perfected Lord of the Wondrous Path of the Unfathomable Void from the Southern Pole established [the Nanji Changsheng Gong]; [the Perfected Lord] perpetually guards this palace, which shall endure as long as heaven and earth.

Another inscription offers the following claim:

此宮之作，因極靈降。今建是宮為生民祈壽，於是奉聞大廷，敕封南極長生宮， 上祝聖壽萬年，宗支悠久。108

This palace was constructed because a supreme numen descended. Today, we build this palace in order to pray for the living people's ${ }^{109}$ longevity. Here, respectfully announcing to the grand court, [we] consecrate the Nanji Changsheng Gong. Above, [we] wish the Sage [i.e., the Emperor] to live as long as ten thousand years, and that the ancestral branches endure for a long time.

Our inscriptions portray Zhu Quan as the Perfected Lord and depict the Nanji Changsheng Gong as a source of blessings, political stability, and longevity. In this respect, Zhu Quan's initiative coheres with Zhu Yuanzhang's deployment of court Daoists, who established altars to control and sublimate vengeful ghosts (Meulenbeld 2015: 132-167). ${ }^{110}$ The record also coheres with the ritual and theological framework of Daoist scriptures. But while in early Daoist scriptures the Nanji Changsheng Gong is located in the Daoist Heavens, Zhu Quan found it necessary to physicalise and give materiality to this exalted sublimation palace in this world. The 'supreme numen' (ji ling 極靈), mentioned in the second inscription, must be the divine Zhu Quan, who is an incarnation of the Southern Pole, to whom the palace is devoted. An incarnated god needs a proper temple.

The archaeological record does not explain what rituals should be conducted in the Nanji Changsheng Gong, but the Jade Slips, for example, demands ritual specialists to worship the Southern Pole according to the sacrifice of the grand immolation (dalao 大牢); this connects the text, and consequently the formation of Zhu Quan's divine persona, to early Ming developments of the

106 Jiangxi sheng bowuguan 2010: 7. Clunas (2013: 145) is aware of this material, but since his goal is to provide a global picture of kingly tombs, the scholar did not explore the inscriptions and their theological significance in his excellent study of kingly material culture.

107 Jiangxi sheng bowuguan 2010: 8 .

108 Jiangxi sheng bowuguan 2010: 8 .

109 The term shengmin 生民 also occurs in the Jade Slips, which preserves a hymn named the Celestial Music of the Three Pure Ones (Sanqing tianyue 三清天樂). One of its verses has that '[We] carefully revere, asking [you] to increase the longevity and lifespan of the living people by leaps and bounds' 謹拜首稽首兮祈生民壽算增 崇. Jade Slips, 151b. But as noticed by Lagerwey in a personal communication, the term occurs as early as the Shijing 詩經.

110 On Taizu, see Schneewind 2008. 
state cult. ${ }^{111}$ In fact, according to the Jade Slips, Zhu Quan was informed by a Daoist priestess about his divine status at a very early age. Regardless of the factuality of this autobiographical account, it is clear that Zhu Quan's divine persona is embedded in a collective notion of personhood. ${ }^{112}$

In mentioning Zhu Quan's divine title, the archaeological record constitutes physical evidence corroborating the reliability of the Pivot's attribution. The inscriptions also corroborate the account offered in the Veritable Records, but they provide a new perspective on the true theological significance of Zhu Quan's mausoleum.

Zhu Quan's divine authorship is not limited to books. Apart from corroborating the reliability of the Pivot's attribution, the archaeological record demonstrates that, as assumed by the authors of the Veritable Records, the Nanji Changsheng Gong was a building devoted to the worship of the Southern Pole. What is more, the inscriptions present Zhu Quan as the divine author cum worship object of his mausoleum. Interestingly, the Pivot follows the same rationale, for the king is the author and one of the worship objects of his calendars.

\subsection{The Pivot and its calendar}

Calendars constitute one of the most important topics of investigation for scholars of religion. ${ }^{113}$ In order to achieve a renewed understanding of Zhu Quan's authorship as the Perfected Lord, we must take into consideration the calendars he composed. Although embedded in Daoist notions of time, Zhu Quan's calendars do not constitute time-reckoning devices. ${ }^{114}$ His calendars describe the Chinese cycle of sacred births and divine inspections, which the king associates with certain ritual programs. One of these calendars may be found in the last chapter of the Pivot. This chapter is of fundamental importance for the investigation of Zhu Quan's apotheosis, for its calendar portrays the king as the Perfected Lord (see fig. 4).

A comparison between the Pivot and the Jade Slips (see table 2) shows that the latter, while representing an expanded version, retained significant aspects of the former's redaction. The Jade Slips ${ }^{115}$ offers an expanded version of this calendar. This comprehensive version records local deities such as Marshal Deng 鄧元帥 ${ }^{116}$ and the Fujianese god Lord of Wuyi 武夷君. Apart from recording an ample trans-local pantheon, the calendar of the Jade Slips reveals a close affinity with the Jiangxi area, where Zhu Quan spent the greater part of his life. Zhu Quan was very fond of the Perfected Man Xu (Xu Zhenjun 許真君) and his Jingming 淨明 legacy. His calendar men-

111 Jade Slips, 33a. This imperial ritual would require the offering of an ox (niu 牛). This record suggests that Zhu Quan elevated the god to a status that it never reached during the time of Zhu Yuanzhang, who would like to have it worshiped according to the standards of the intermediary sacrifice (zhongsi 中祀). For related records, see Veritable Records/Taizu/37.745; 44.872; 45.882; 45.883; 52.1027.

112 According to Richard Wang (2012: xvi), the king 'claimed a divine identity with Nanji chongxu miaodao zhenjun.' To my knowledge, this view first appears in the Zhu Zhenren zhuan 朱真人傳 (Biography of the Perfected Man Zhu [Quan]), a late Ming hagiography depicting the Ming king as a Jingming 净明 patriarch. The anonymous compilers of this biography, certainly drawing from the Jade Slips, claimed that Zhu Quan 'called himself' (zicheng 自稱) the Perfected Lord from the Southern Pole. See 'Zhu Zhenren zhuan', 5.48. I avoid this sort of naive biographism.

113 See, for example, Stern 2001, and Nothaft 2014.

${ }_{114}$ In the Jade Slips, however, notions of time measurement and related terminologies abound. Zhu Quan's divine persona, the Southern Pole, is an astrological deity and, consequently, a god connected to notions about time.

115 For a discussion of the Jade Slips' publication context, see Schachter 2018b.

116 淡火大神生. Jade Slips, 215a. 


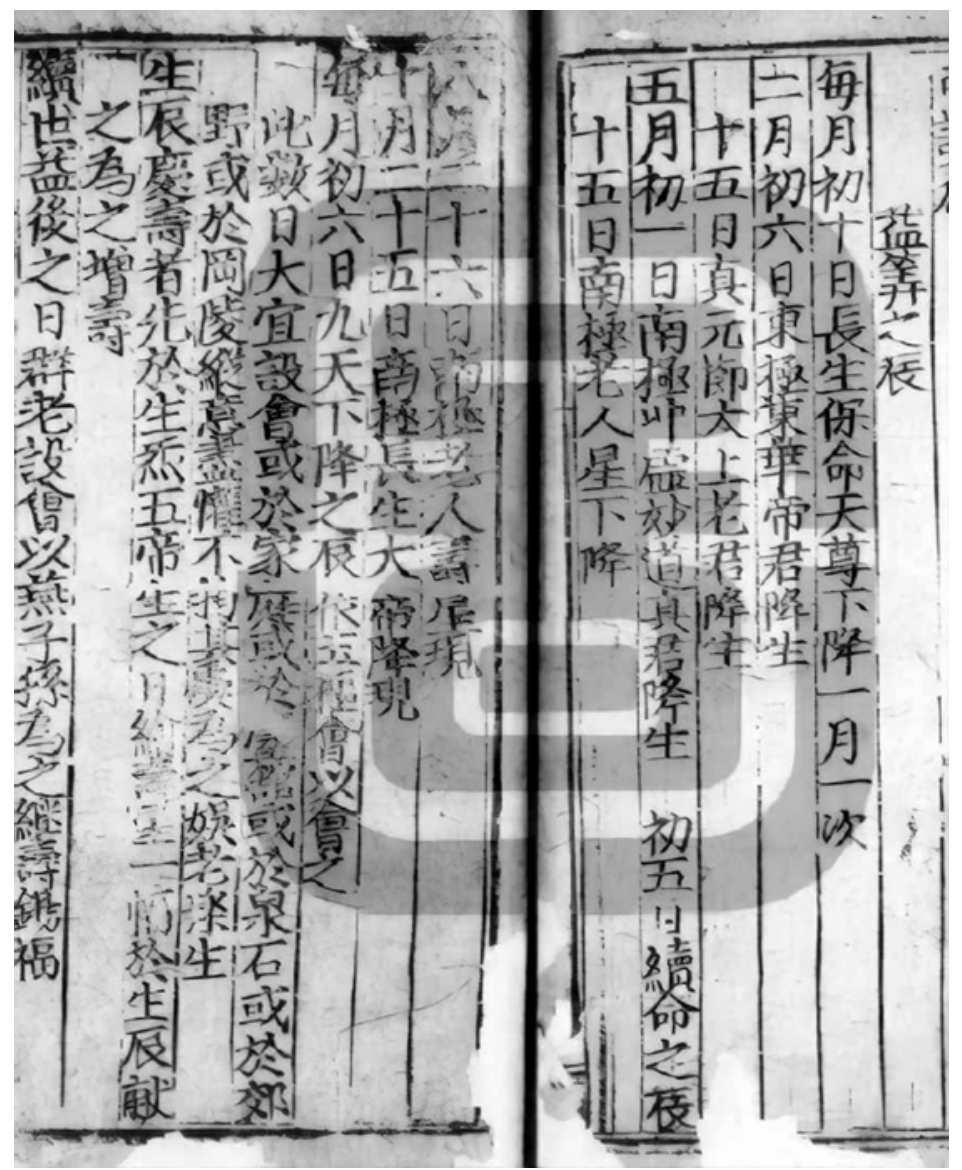

Fig. 4 - Zhu Quan's Calendar in Chenghua Edition (E1).

tions Xu's sacred birth, which takes place on the twenty-eighth day of the first lunar month, ${ }^{117}$ as well as his ascension on the traditional date seen in early hagiographies, i.e., the fifteenth day of the eighth month. ${ }^{118}$ The calendar seen in the Pivot, on the other hand, focuses on the manifestations of the Southern Pole. In both calendars, nevertheless, Zhu Quan's image as a god seems to parallel the profile of his intended audience, for both the Perfected Lord and his implied readers are elderly gentlemen of elite background.

According to passage 4, the Perfected Lord was born on 05/01. This is exactly the same birth date offered in the Grave Epitaph of the King of Ning (Ningwang Kuangzhi 寧王壙志), which states that 'The king was born on 05/01 of Hongwu 11.'119 Zhu Quan's birthday overlaps with Nanji Changsheng Dadi's sacred birth, which is celebrated on the same date. This explains why

\footnotetext{
117 二十八日許真君誕生. Jade Slips, 209b.

118 Jade Slips, 219a.

119 王生於洪武十一年五月初一日. Jiangxi sheng bowuguan 2010: figure no. 10.
} 
our sources portray Zhu Quan as the incarnation of the Southern Pole, rather than any other particular god. Our calendars mention Zhu Quan's birthday, but they do not explore his mundane aspects, which the redactors of the Veritable Records mercilessly exposed. In addition, the Wanli edition of the calendar offers the following claims: (1) '[On 12/21] the Perfected Lord meets the immortals.' ${ }^{120}$ (2) '[On 12/27] the Perfected Lord received the Dao from the Perfected Lord of Universal Salvation.'121 These statements demonstrate that in Zhu Quan's writings, biography and theology form an integrated whole. In some paratexts, this integration occurs in an even more radical manner, but this discussion will have to be left for another contribution.

Passage 9 mentions a certain Assembly of the Jade Pivot, or Yushu hui 玉樞會. The Jade Slips mentions a certain Yushu hui jiao yi 玉樞會醮儀, or the Offering Ritual of the Assembly of the Jade Pivot. ${ }^{122}$ The term Yushu hui, therefore, points to a Jiao service. It appears eleven times in the Wanli editions of the Jade Slips, according to which 'on this day [i.e., the sixth day of the month], one must establish an Assembly of the Jade Pivot in order to guarantee peace for one month.' ${ }^{123}$ The Pivot corroborates the Jade Slips' redaction: 'The Nine Celestials descend on the sixth day of every month, so that one must gather with them, in accordance with the Jade Pivot's Assembly.'124 Although I translate it as 'Nine Celestials', the term jiutian 九天 may point to the Celestial Worthy of Universal Transformation (Jiutian yingyuan leisheng puhua tianzun 九天應元雷聲普化 天尊), who 'emerged during the twelfth century as the supreme authority in charge of the new Thunder Department (Leibu 雷部)', ${ }^{125}$ being the principal god of the Scripture of the Jade Pivot (Yushu jing 玉樞經). ${ }^{126}$ This scripture, or at least its theological framework, most probably constituted the central theme of the aforementioned Offering. This is suggested by a passage in which the Jade Slips states that on the sixth day of the month 'the Thunder Gods of the five directions descend [to the human realm].'127

The Pivot describes the Assembly of the Jade Pivot in relation to the needs of an elite audience of respectable elders. Its last chapter shows that the calendar of the 1472 edition, whose fragments also survive in the Jade Slips, should benefit this specific target group. Longevity is the main theme of Zhu Quan's calendar. In the Jade Slips, longevity is described (1) as an object of social anxiety; (2) as the result of strict religious observance; (3) as achieved through tending life practices; (4) as possessing a karmic aspect to it; (5) as a matter of divine interference. ${ }^{128}$ The book claims that human longevity is endowed (bingfu 禀賦) by the Three Principles (San yuan 三元). The inferior longevity, corresponding to $60 \mathrm{sui}$, belongs to the Celestial Principle (tianyuan 天 元). The medium longevity, associated with the Earth Principle (diyuan 地元), corresponds to a lifespan of 120 sui, while the superior longevity - relating to the Human Principle (renyuan 人 元) - corresponds to 180 sui. Although the Chenghua edition of 1472 attributes this tripartite

120 南極沖虛妙真君遇仙. Jade Slips, 226a.

121 南極沖處妙道真君受道於普度真君. Jade Slips, 227b.

122 Jade Slips, 37b.

123 其日建玉樞會以保一月之安. Jade Slips, 212a.

124 每月初六日九天下降之辰依玉樞會以會之.E1,3.45a.

125 Andersen 2019: 172. Andersen (2019: 171-77) makes many important remarks on this deity.

126 On this scripture and its editions, see Wan 2010: 135-183.

127 五方雷神下降. Jade Slips, 213b.

128 Jade Slips, 32b, 83b, 118b, 180a-180b. 
scheme to the deified Zhu Quan, this conceptual formulation of longevity seems to predate his authorial activities. ${ }^{129}$

The Pivot's calendar addresses an elite audience of respectable male elders and their need for securing and 'expanding longevity', or extending life beyond the limits of the 'inferior longevity', defined by that book as 60 sui: 'those of elevated age must, on their birthday, perform the Banquet for Extending the Years of the Old Gentlemen [Qilao yanling hui 者老延齡之會, hereafter, Banquet]. ${ }^{\prime 30}$ One day before the Banquet, the elder in question should 'drink [alcohol] in the company of all the elders.'131 This first reunion, the text names nuanshou 暖壽. This custom is recorded in many Ming-Qing sources. Zhao Yi’s 趙翼 (1727-1814) Miscellaneous Notes from My Mourning Period (Gaiyu congkao陔餘叢考), for example, explains that, according to what he terms 'vulgar customs' (suli 俗禮), nuanshou refers to drinking alcohol with friends on the day before one's birthday. ${ }^{132}$

Concerning the entertaining aspects of this reunion, the Chenghua edition advises the elders to 'fully rejoice' (jin huan 盡懽) themselves. Wine is a fundamental element of the gathering, so that 'those who violate the agreement must be penalised with one huge gong 觥 [i.e., a zoomorphic ewer] for each transgression. ${ }^{133}$ On this special occasion, therefore, the elders have no need to observe the principles of frugality and moderation usually associated with longevity lore, which recommends emotional and dietary restrictions. The host, also termed in this passage as 'he who celebrates his longevity' (qingshouzhe 慶壽者), should 'draw one picture of the [god named] Longevity Star' (hui Shouxing yi fu 繪壽星一幅) on the birthday of one of the Five Thearchs (Wu Di 五帝) and offer (xian 獻) it during his own birthday, in order 'to increase longevity' (zeng shou 增 壽). Apart from one icon of the Longevity Star, the text recommends the use of incense, noodles ( mian 麵), and wine. By the morning, the elders should gather to celebrate, drink wine, and revere the Longevity Star. The text claims that the Banquet (or, alternatively, the Assembly of the Jade Pivot) may be conducted in various places, including one's home, natural spots such as springs and mountains (quanshi 泉石) as well as ridges and hills (gangling 岡陵). The elders are urged to establish an Assembly of the Jade Pivot: 'On these days, it is very appropriate to establish an Assembly.' Zhu Quan's apotheosis derives its connection with the world of ritual by virtue of the king's self-incorporation into the calendrical cycle of Daoist festivities. In the next section, I explore the relationship between text and ritual.

\subsection{Calendars and the problem of ritual textualisation}

Zhu Quan's calendars constitute legitimate materials through which to discuss the problem of ritual textualisation. ${ }^{134}$ As Grimes puts it: 'Most of us scholars, most of the time, analyze not rituals but renditions of rituals, substitutes that we sometimes lapse into treating as if they were the real

\footnotetext{
129 Indeed, the locus classicus of this tripartite formulation is the Book of the Three Principles for Longevity Equal to Heaven and Earth (Sanyuan yanshou canzan shu 三元延壽參贊書), attributed to the Yuan person Li Pengfei 李鵬飛 (fl. 1291). On this text, see Schipper 2004: 790-791.

$130 \mathrm{E} 1,3.43 \mathrm{~b}$.

131 與眾老會飲. E1, 3.43b.

132 俗禮有所謂暖壽、暖房者，生日前一日，親友治具過飲曰：暖壽. Gaiyu congkao, 43.598.

133 違約者每事罰一巨觥. E1, 3.44a.

134 Bell 2009: 138-39.
} 
thing. ${ }^{135}$ In the particular case of ritual texts, we have access to descriptions, remarks, instructions, complete or incomplete manuals, but not actual rituals. To paraphrase art historian Baxandall, we do not describe rituals, but what we think about them. ${ }^{136}$ The distinction between scholars and ritualists is assumed as a matter of purpose. The ritualist textualises ritual for a multitude of non-scholarly concerns. Since ritual texts are not rituals, they give privileged access to a great deal of information about how specific ritualists and ritual communities imagine and frame their practices. Some believe that an ethical imperative distinguishes the scholarly practice from the ritualist's textualisation of rituals. ${ }^{137}$ However, unabashed by our post-Enlightenment habits, in composing his calendars Zhu Quan acted both as a scholar and as a ritualist.

The preface presents the Pivot as a scholarly work, while its last chapter evidences Zhu Quan's research of ritual texts. In the specific case of the Banquet, the king did not describe actual rituals, but worked on the basis of existing texts. We know this because his textual description of the Banquet is not exclusive to the Pivot. It conflates with the description found in other Ming-Qing editions. The passage in question partially overlaps with Sima Guang's 司馬光 (1019-1086) version of the Banquet, named the 'Authentic Banquet of the Meritorious Elders', or Qiying zhenshuai hui 者英真率會. ${ }^{138}$ The locus classicus of this Song dynasty Banquet of elders seems to be Wen Yanbo's 文彥博 (1006-1097) biography in the History of Song (Songshi 宋史), according to which the Banquet dates to Tang times:

\section{與富㢶 、司馬光等十三人，用白居易九老會故事，置酒賦詩相樂，序齒不序官， 為堂繪像其中謂之《洛陽者英會》。好事者莫不慕之。}

[Wen Yanbo], along with Fu Bi 富貆 [1004-1083], Sima Guang and 13 other people, inspired by Bai Juyi's stories about the Reunion of the Nine Elders, brought wine and entertained each other with poems. They organised [this Assembly] according to age, not rank, making a hall within which they produced a picture, naming it the Assembly of Luoyang's Meritorious Elders. Among those who love good things, there is not even a single person who would not admire it. ${ }^{139}$

The Banquet consists of a joyous gathering between elders. All editions that record the Banquet make a distinction between the host ( $z h u$ 主) and the guests ( $k e$ 客). On this special occasion, their hierarchical relationship is defined in terms of age, instead of social position. The sentence $x u$ chi bu xu guan 序齒不序官 means that the gathering should have age, not rank, as an organisational criteria. It literally means 'arrayed according to teeth, not according to office', in a humorous reference to the elders' deteriorating oral health: the less the number of teeth, the longer one has lived and, therefore, the higher should be one's position in this reunion.

The Chenghua version of the Banquet is unique in several aspects. First, it does not establish a connection between the Banquet and Sima Guang. This may have occurred for many reasons. It is possible that, in the Ming context, an elite audience would immediately understand the connec-

135 Grimes 2014: 81.

136 Baxandall 1986: 1: 'We do not explain pictures: we explain remarks about pictures'.

137 Gruenwald (2003: 35), for example, argues that: 'The scholar does not attempt, in any way, to persuade people to do the ritual as a religiously meaningful act. No sides are taken, and all forms of propaganda are shunned.'

138 For example, Ming-Qing editions of the An'lao huaiyou shu 安老懷幼書, the Siyou zhaicong shuo 四友斎叢說, and the Shouqin yanglao xinshu 壽親養老新書 record the same Banquet, which they attribute to Wen Yanbo.

139 Songshi, 313.236. 
tion between Zhu Quan's text and Sima Guang's story. One cannot interpret paratextual silence as plagiarism. Second, this edition gives particular emphasis on the joyous aspect of the reunion, recommending the participants to entertain themselves with wine, poetry, music, and dance, 'rejoicing spontaneously in order to satisfy one's volitions.' ${ }^{140}$ Third, and most importantly, the Pivot suggests that 'on one's birthday it is also appropriate to establish a Jiao in order to supplicate Nanji for longevity.' ${ }^{141}$ The mentioned Offering is, without a doubt, an Offering of the Jade Pivot. The Pivot demands that participants worship the Southern Pole, of which Zhu Quan is a Ming incarnation, before and during the Banquet. By doing so, the king imposes his authorial mark upon his own version of the Banquet.

Zhu Quan's Banquet is not a first-hand account of a ritual that he saw or practiced, but a scholarly operation of textual selection, reduplication, and reorganisation. The king did not textualise rituals. Zhu Quan ritualised his own textual production, for his calendar is the work of a ritualist. Zhu Quan's goal is to inculcate a ritual sense ${ }^{142}$ in his audience. Regardless of theological symbolism, the ritual purpose of Zhu Quan's apotheosis is frankly normative. The calendar is not much about instilling belief or communicating theological notions. It reflects an attempt at altering its audience's relationship with time and existing ritual cycles as defined by calendars. One of its purposes must be the creation of a new social behavior: keeping the sanctity of the king's birthday. In order to achieve this goal, the Pivot proposes a win-win situation: on the one hand, the divine Zhu Quan achieves the supreme goal of historical longevity, which Laozi defines in the following terms: 'Those who die without falling into oblivion [have achieved] longevity' (si bu wang zhe shou ye 死不忘者壽也). ${ }^{143}$ On the other hand, his readers could benefit from esoteric teachings and, ritualising the Perfected Lord's memory as a calendrical god, attain physical longevity.

\section{FINAL REMARKS}

Devoted to the problem of Zhu Quan's apotheosis, this article examined how the Pivot constructs his authorship. The first section offered a brief description of the Pivot's extant editions. This was a necessary step because both editions play an equally important role in my examination of authorship. The second section examined the Pivot's preface in terms of its paratextual performance. As a form of autobiographical discourse, the preface describes the Pivot as Zhu Quan's scholarly accomplishment. This paratext suggests that Zhu Quan finished the Pivot during the Zhengtong reign. The preface also reflects social realities such as the political significance of almanacs and transformations in the field of esoteric transmission. The last section discussed the ritual underpinnings of Zhu Quan's divine authorship. In this connection, this article demonstrated the relevance of the Pivot and its calendar for recent debates about ritual textualisation. Zhu Quan's calendar reflects, simultaneously, the king's textual research and his attempt at altering its audience's relationship with time and existing rituals. The calendar materialises his performance

\footnotetext{
140 縱樂自如以快其志. E1, 3.44a.

141 生辰亦是宜設醮祈壽於南極. E1, 3.44a.

142 On this notion, see Quack 2010: 169-88.

143 Laozi Mawangdui Hanmu boshu jiaben Daojing 老子馬王堆漢墓帛書甲本道經.
} 
as a scholar motivated by ritual concerns. Whether the Pivot reveals Zhu Quan's mystical experience or not is, so to say, immaterial and irrelevant. The Pivot, as seen from this investigation of Zhu Quan's calendars, is a work of material apotheosis.

Table 1 - The Pivot and Its Contents

\begin{tabular}{|c|c|}
\hline Chapter Name & Content \\
\hline $\begin{array}{l}\text { 1. Xuanming qianxiang zhang 宣明 } \\
\text { 乾象章 (The Proclamation of Light } \\
\text { and the Image of the Creative; E1, } \\
\text { 1.5b-18b; E2, 1.6a-15b). } \\
\text { 2. Chengqian fuying zhang 承乾符應 } \\
\text { 章 (Inheriting the Creative and Echoing } \\
\text { the Transformations; E1, 1.18b-46a; } \\
\text { E2, 1.16a-46b). }\end{array}$ & $\begin{array}{l}\text { Together, these two chapters constitute the so-called 'first scroll', or } \\
\text { 上卷 shangjuan. The first chapter presents six methods (fa 法) for } \\
\text { climatic prognostication. The second chapter concerns seven such } \\
\text { methods, as well as methods for calendrical calculation. }\end{array}$ \\
\hline $\begin{array}{l}\text { 3. Houqi jingshi zhang 候氣經式 } \\
\text { 章 (Weather Prognostications, its } \\
\text { Scriptures and Boards; E1, 2.1a-6a; E2, } \\
\text { 2.1a-5b). }\end{array}$ & $\begin{array}{l}\text { This is the first chapter of the 'last scroll', or xiajuan 下卷. It com- } \\
\text { prises thirteen methods related to qimen and agricultural lore. Most } \\
\text { of these entries describe methods for determining specific dates of } \\
\text { great importance for an agrarian society. It also describes the ritual } \\
\text { programs to be adopted on these special days. During the first xin 辛 } \\
\text { day of the year, for example, one should 'supplicate for cereals and } \\
\text { worship the Ancient Thearchs.' }{ }^{144}\end{array}$ \\
\hline $\begin{array}{l}\text { 4. Shenfu kunyun zhang 神符坤運章 } \\
\text { (The Divine Symbol and the Revolutions } \\
\text { of the Receptive; E1, 2.6a-26b; E2, } \\
\text { 2.6a-24b). }\end{array}$ & $\begin{array}{l}\text { This long chapter comprises no less than seventeen entries on } \\
\text { fengshui 風水 methods. }{ }^{145} \text { The first entry, for example, concerns the } \\
\text { structure of the 'compass', or pan 盤. }\end{array}$ \\
\hline $\begin{array}{l}\text { 5. Tianhuang aoji zhang 天皇摮極 } \\
\text { 章 (The Celestial Luminaries and the } \\
\text { Turtle Poles; }{ }^{46} \text { E1, 2.27a-35b; E2, } \\
\text { 2.25a-32b). }\end{array}$ & $\begin{array}{l}\text { This chapter comprises seven entries, the majority of which are } \\
\text { calculations involving the concept of five } q i \text { 氣, which are the } \\
\text { five oriented energies. It presents methods for the calculation of } \\
\text { the relationship between these five qi, the Taisui 太歲 and other } \\
\text { astronomical phenomena. }\end{array}$ \\
\hline
\end{tabular}

144 祈轂祀上帝. E1, 2.4a.

$145 \mathrm{E} 1,2.17 \mathrm{a}$.

${ }^{146}$ The term aoji 鰲極 refers to a legend according to which Nüwa 女媧 cut off the limbs of a divine turtle in order to use them as the four poles ( $j i$ 極) or pillars supporting the sky. 


\begin{tabular}{|c|c|}
\hline Chapter Name & Content \\
\hline $\begin{array}{l}\text { 6. Shenji guicang zhang 神機鬼藏 } \\
\text { 章 (The Divine Mechanism and the } \\
\text { Demonic Repository; E1, 3.1a-29a; E2, } \\
\text { 2.33a-59b). }\end{array}$ & $\begin{array}{l}\text { This chapter offers thirteen methods. The first section explains its } \\
\text { contents as a matter of 'stealing from the Creation-Transformation. }{ }^{147} \\
\text { It identifies the auspicious and inauspicious days for all types of } \\
\text { activities, including construction, funerals, marriages, etc. It presents } \\
\text { tables for the identification of the auspicious and inauspicious gods } \\
\text { of the year. This chapter seemingly existed as a separate book during } \\
\text { the Qing. }{ }^{148}\end{array}$ \\
\hline $\begin{array}{l}\text { 7. Qianxu keying zhang 潛虛克應章 } \\
\text { (Sinking into the Void and Conquering } \\
\text { the Transformations; E1, 3.29b-36a; } \\
\text { E2, 2.60a-66b). }\end{array}$ & $\begin{array}{l}\text { This chapter consists of six entries, all dealing with divination practic- } \\
\text { es. The first entry describes divination as a phenomenological activity } \\
\text { involving the three essentials (sanyao 三要), which are the ears, } \\
\text { the eyes, and the mind. The other entries teach the reader how to } \\
\text { interpret various sorts of apparently trivial phenomena. For example, } \\
\text { the occurrence of a fire may be interpreted as an omen that foretells } \\
\text { the destiny of families. }\end{array}$ \\
\hline $\begin{array}{l}\text { 8. Shenguang huming zhang 神光護命 } \\
\text { 章 (The Divine Light that Protects Life; } \\
\text { E1, 3.36b-43a; E2, 2.67a-70b). }\end{array}$ & $\begin{array}{l}\text { This chapter comprises three methods. The first entry is a method for } \\
\text { the fabrication of the Numinous Talisman of the Most High (Tais- } \\
\text { hang Lingfu 太上靈符). This talisman destroys the three corpses } \\
\text { (sanshi 三尸) that obstruct the cultivation of the Dao. The second } \\
\text { entry describes the functions of the divine light (shenguang 神光), } \\
\text { corresponding to a textual tradition very similar to that recorded } \\
\text { in the Scripture of the Divine Light of the Celestial Elder (Tianlao } \\
\text { shenguang jing 天老神光經). }{ }^{149} \text { The last entry offers methods for the } \\
\text { prognostication of auspicious and inauspicious omens. Commenc- } \\
\text { ing from vol.2, pages } 41 b-42 a \text {, E2 shows signs of increasing paper } \\
\text { deterioration. In E2 this chapter commences in page } 67 \text { and survives } \\
\text { only in fragmentary form. E2 ends abruptly in the middle of this chap- } \\
\text { ter, corresponding to the content of E1, 3.36b-39b/Line } 8 \text {. }\end{array}$ \\
\hline $\begin{array}{l}\text { 9. Baohe taihe zhang 保合太和章 } \\
\text { (The Preservation of Harmony and the } \\
\text { Supreme Peace; E1, 3.43b-46b). }\end{array}$ & $\begin{array}{l}\text { This last chapter consists of four entries. These are: (1) Banquet for } \\
\text { Extending the Years of the Old Gentlemen (Qilao yanling hui 老老 } \\
\text { 延齡會). (2) Auspicious Days for Establishing a Longevity Offering } \\
\text { (Jianyan shengjiao jiri 建延生醮吉日). (3) Days that Augment the } \\
\text { Lifespan (Yisuan zhi chen 益算之辰). (4) Period for the Enjoyment of } \\
\text { Liquor (Huanbo zhi qi 歡伯之期). E1 partially preserves this chapter, } \\
\text { whose corresponding pages are missing from E2. }\end{array}$ \\
\hline
\end{tabular}

147 奪造化. E1, 3.1a.

148 See Siku quanshu zongmu, 110.1826, which describes an edition named Shenshu guicang jing 神樞鬼藏經, now lost.

149 On this scripture, see Schipper 2004: 1244-1245. 
Table 2 - The Perfected Lord in Chenghua and Wanli Editions

\begin{tabular}{|c|c|}
\hline $\begin{array}{l}\text { Content in the } 1472 \text { Edition of the Pivot } \\
\text { Yisuan zhi chen 益算之辰 (E1, 3.44b-45a), see fig. } 4\end{array}$ & $\begin{array}{l}\text { Corresponding Content in the } 1607 \text { Edition } \\
\text { of the Jade Slips } \\
\text { Chaoxiu jichen zhang 朝修吉辰章 }\end{array}$ \\
\hline $\begin{array}{l}\text { Passage } 1 \\
\text { 44b/8: 每月初十日長生保命天尊下降一月一次 }\end{array}$ & $\begin{array}{l}\text { (1) 208b; (2) 210b; (3) 212b; (4) 214a; (5) 216b; } \\
\text { (6) 218a; (7) 219b; (8) 222b; (9) 224a; (10) 225b: } \\
\text { 初十日長生保命天尊下降 }\end{array}$ \\
\hline $\begin{array}{l}\text { Passage } 2 \\
\text { 44b/9: 二月初六日東極東華帝君降生 }\end{array}$ & 210a: 初六日東極東華帝君降生 \\
\hline $\begin{array}{l}\text { Passage } 3 \\
\text { 44b/10: 十五日真元節太上老君降生 }\end{array}$ & $\begin{array}{l}\text { 211a: 十五日真元節三教宗師太上老君混元道 } \\
\text { 徳皇帝誕生西斗下降 }\end{array}$ \\
\hline $\begin{array}{l}\text { Passage } 4 \\
\text { 44b/11: 五月初一日南極沖虛妙道真君降生 }\end{array}$ & $\begin{array}{l}\text { 215a: 五月初一日延生節太上老君傳三天正法 } \\
\text { 付漢天師天帝持東井南極冲虚妙道真君下降 }\end{array}$ \\
\hline $\begin{array}{l}\text { Passage } 5 \\
\text { 44b/11: 初五日續命之辰 }\end{array}$ & $\begin{array}{l}\text { 215a: 初五日續命之辰太乙救苦天尊下降天蓬 } \\
\text { 翊聖真君下降真武下降北斗出持欻火大神生葉 } \\
\text { 道元天師降伏婆羅門妖幻救龍尼難 }\end{array}$ \\
\hline $\begin{array}{l}\text { Passage } 6 \\
\text { 44b/12: 十五日南極老人星下降 }\end{array}$ & $\begin{array}{l}\text { 215b: 十五日太上老君降現鶴鳴山南極老人星 } \\
\text { 下降西斗下降 }\end{array}$ \\
\hline $\begin{array}{l}\text { Passage } 7 \\
\text { 45a/1: 八月二十六日南極老人壽星現 }\end{array}$ & 220a: 二十六日南極老人專星現 \\
\hline $\begin{array}{l}\text { Passage } 8 \\
\text { 45a/2: 十月二十五日南極長生大帝降現 }\end{array}$ & $\begin{array}{l}\text { 223b: 二十五日天符節南極長生大帝降現天蓬 } \\
\text { 下降 }\end{array}$ \\
\hline $\begin{array}{l}\text { Passage } 9 \\
\text { 45a/3: 每月初六日九天下降之辰依玉樞會以會之 }\end{array}$ & $\begin{array}{l}\text { 208b (1st lunar month): 初六日建玉樞會以保一 } \\
\text { 月之安 } \\
\text { 210a, 212a, 213b, 215a, 216b, 218a, 221a, 222b, } \\
\text { 224a, 225b. }\end{array}$ \\
\hline
\end{tabular}




\section{REFERENCES}

1. Primary Sources

1.1 The Zhouhou shenshu and Its Editions

Zhu Quan 朱權. Zhouhou shenshu 肘後神樞 [The Divine Pivot Ready to Hand]. Chenghua 8 (1472) edition. Code: 04499. Beijing: National Library of China.

Zhu Quan 朱權. Zhouhou shenshu 肘後神樞 [The Divine Pivot Ready to Hand]. Qing edition (?). Code: 15569. Beijing: National Library of China.

\subsection{Official Histories, Catalogues, and Other Compilations}

\subsubsection{Official Histories}

Ming shilu 明實錄 [Veritable Records of the Ming]. 1418-mid-seventeenth century. Academia Sinica, Hanji quanwen ziliaoku 漢籍全文資料庫 (Scripta Sinica) database.

Shiji 史記 [Records of the Grand Historian]. Siku Quanshu edition. Kanseki Repository. 漢籍リポジトリ.

Songshi 宋史 [History of Song]. Wuyingdian edition. Zhongguo guji jiben ku 中國古籍基本庫 database.

Beijing: Beijing Airusheng shuzihua jishu yanjiu zhongxin.

Taizu baoxun 太祖寶訓 [Precious admonitions of the supreme ancestor]. Academia Sinica, Scripta Sinica.

\subsubsection{Catalogues}

Chao Li 昆瑮 (1507-1560). Baowentang shumu 寶文堂書目 [Book Catalogue of the Hall of Precious Writs]. Ming manuscript edition. Zhongguo guji jiben $k u$.

Haifeng Wushi cangshu mu 海豐吳氏藏書 [Book catalogue of the Wus, from Haifeng]. Qing dynasty edition. Code: 05819. Beijing: National Library of China.

Siku quanshu zongmu 四庫全書總目 [General Catalogue of the Complete Library in Four Sections]. Qianlong Wuyingdian edition. Zhongguo guji jiben $\mathrm{ku}$.

\subsubsection{Others}

Dounan laoren ji 斗南老人集 [Anthology of the Old Man Dounan]. Siku Quanshu edition. Kanseki Repository.

Dounan xiansheng shiji 斗南先生詩集 [Poetical Anthology of Master Dounan]. Code: 17213. Beijing: National Library of China.

Hu Yan 胡儼 (1360-1443). ‘Chi feng jian Nanji Changsheng Gong ji 敕封建南極長生宮記 [Record on the Construction of the Nanji Changsheng Gong].' In: Xishan zhi 西山志 [Gazetteer of Xishan]. Qianlong 31 (1766) edition. Zhongguo guji jiben $k u$.

Yuefu shi ji 樂府詩集. Siku Quanshu edition. Kanseki Repository.

Zhao Yi 趙翼 (1727-1814). Gaiyu congkao 陔餘叢考 [Miscellaneous Notes from My Mourning Period]. Qianlong 55 (1790) edition. Zhongguo guji jiben ku.

Zhou Renjia 周人甲 (Qing dynasty?). Guanli huizhan 管蠡匯占. Daoguang (1821-1850) edition. Zhongguo guji jiben ku.

Zhou Yi 周易. Kanseki Repository (KR1a0001).

Zhu Quan (1378-1448). Shenyin 神隱 [Divine Hermitage]. Wanli edition (Qing reprint?) published by Hu Wenhuan 胡文煥 (fl. Wanli). Code: 02889. Beijing: National Library of China. 
Zhu Zhenren zhuan 朱真人傳 [Biography of the Perfected Man Zhu].' In: Jin Guixin 金桂馨 (ed.) Xiaoyao shan Wanshou gong zhi 逍遙山萬壽宮志 [Gazetteer of the Wanshou Palace, on Mount Xiaoyao]. Guangxu 4 (1878) edition. Zhongguo guji jiben ku.

\subsection{Daoist Scriptures in the Ming Canon}

DZ 15 Wushang Jiuxiao Yuqing Dafan Ziwei Xuandu Leiting Yujing 無上九霄玉清大梵紫微玄都雷霆玉經 DZ 22 Yuanshi wulao chishu yupian zhenwen tianshu jing 元始五老赤書玉篇真文天書經

DZ 87 Yuanshi wuliang duren shangpin miaojing sizhu 元始无量度人上品妙經四註

DZ 89 Yuanshi wuliang duren shangpin miaojing tongyi 元始無量度人上品妙經通義

DZ 90 Yuanshi wuliang duren shangpin miaojing neiyi 元始无量度人上品妙經内義

DZ 97 Taishang lingbao zhutian neiyin ziran yuzi 太上靈寶諸天內音自然玉字

DZ 405 Shangqing Zijing Jun Huangchu ziling daojun dongfang shangjing 上清紫精君皇初紫靈道君洞房 上經

DZ 466 Lingbao lingjiao jidu jinshu 靈寶領教濟度金書

DZ 547 Lingbao yujian 靈寶玉鑒

DZ 615 Chisongzi zhangli 赤松子章曆

DZ 851 Sanyuan yanshou canzan shu 三元延壽參贊書

DZ 866 Tianlao shenguang jing 天老神光經

DZ 885 Huangdi jiuding shendan jingjue 黃帝九鼎神丹經訣

DZ 1376 Shangqing taishang dijun jiuzhen zhongjing 上清太上帝君九眞中經

DZ 1377 Shangqing taishang jiuzhen zhongjing jiangsheng shendan jue 上清太上九負中經絳生神丹訣

DZ 1168 Yunji qiqian 雲笈七賳

DZ 1483 Tianhuang zhidao taiqing yuce 天皇至道太清玉冊

Secondary Sources

Acker, Peter 2006. Liu Chuxuan (1147-1203) and His Commentary on the Daoist Scripture Huangdi yinfu jing. Wiesbaden: Harrassowitz Verlag.

Andersen, Poul 2019. The Paradox of Being: Truth, Identity, and Images in Daoism. Cambridge and London: Harvard University Asia Center.

Barrett, Timothy H. 2001. 'The Rise and Spread of Printing: A New Account of Religious Factors.' SOAS Working papers in the Study of Religions, 1-40.

Barrett, Timothy H. 2008. The Woman Who Discovered Printing. London: Yale University Press.

BaXANDALL, Michael 1986. Patterns of Intention: On the Historical Explanation of Pictures. New Haven and London: Yale University Press.

Beecroft, Alexander 2010. Authorship and Cultural Identity in Early Greece and China. Cambridge: Cambridge University Press.

BeLl, Catherine 2009. Ritual Theory, Ritual Practice. Oxford: Oxford University Press.

Berensmeyer, Ingo, Gert Buelens and Marysa Demoor (eds.) 2019. The Cambridge Handbook of Literary Authorship. Cambridge: Cambridge University Press.

Berling, Judith 1998. 'Taoism in Ming Culture.' In: Dennis Twitchett and Frederick W. Mote (eds.) The Cambridge History of China, Volume 8, The Ming Dynasty, 1368-1644, Part 2. Cambridge: Cambridge University Press, 953-986. 
Bokenkamp, Stephen 1997. 'The Yao Boduo stele as evidence for the 'Dao-Buddhism' of the early Lingbao scriptures.' Cahiers d'Extrême Asie 9: 55-67.

Bokenkamp, Stephen 2007. Ancestors and Anxiety: Daoism and the Birth of Rebirth in China. Berkeley: University of California Press.

Boltz, Judith 2008a. 'Tianhuang zhidao taiqing yuce.' In: Fabrizio Pregadio (ed.) The Encyclopedia of Taoism. London-New York: Routledge, 974-976.

Boltz, Judith 2008b. 'Zhu Quan.' In: Fabrizio Pregadio (ed.) The Encyclopedia of Taoism. London-New York: Routledge, 1294-1295.

Burke, Seán 2003. Authorship: from Plato to the Postmodern, a Reader. Edinburgh: Edinburgh University Press.

Burke, Seán 2008. The Ethics of Writing: Authorship and Legacy in Plato and Nietzsche. Edinburgh: Edinburgh University Press.

DE Bruyn, Pierre-Henry 2000. 'Daoism in the Ming.' In: Livia Kohn (ed.) Daoism Handbook. Leiden: Brill, 594-622.

Campany, Robert 2009. Making Transcendents: Ascetics and Social Memory in Early Medieval China. Honolulu: University of Hawaii Press.

Castle, Gregory 2007. The Blackwell Guide to Literary Theory. Oxford: Blackwell Publishing.

Chan, Hok-Lam 1998. 'The Chien-wen, Yung-lo, Hung-hsi, and Hsuan-te reigns.' In: Dennis TwitchetT and Frederick W. Mоте (eds.) The Cambridge History of China, Volume 7, The Ming Dynasty, 13681644, Part 1. Cambridge: Cambridge University Press, 184-204.

Davis, Walter B. 2014. 'Art, Aesthetics, and Religion in Modern China.' In: Vincent Goossaert, Jan KielY, and John Lagerwey (eds.) Modern Chinese Religion II: 1850-2015. Leiden: Brill, 197-257.

DrÈge, Jean Pierre 1991. Les bibliothèques en Chine au temps des manuscrits: jusquảu Xe siècle. Paris: École française d'Extrême-Orient.

EAgleton, Terry 1996. Literary Theory: An Introduction. Oxford: Blackwell Publishing.

Ebrey, Patricia 2014. Emperor Huizong. Cambridge and London: Harvard University Press.

FisCHER, Paul 2008-2009. 'Authentication studies (辨偽學) methodology and the polymorphous text paradigm.' Early China 32: 1-43.

Franke, Wolfgang 2011. Annotated Sources of Ming History: Including Southern Ming and Works on Neighbouring Lands 1368-1661. Kuala Lumpur: University of Malaya Press.

Goossaert, Vincent and David Palmer 2011. The Religious Question in Modern China. Chicago: The University of Chicago Press.

Gruenwald, Ithamar 2003. Rituals and Ritual Theory in Ancient Israel. Leiden: Brill.

HAN Rongjun 韓榮鈞 and Sun Caishun 孫才順 2013. Qingdai Haifeng Wushi jiazu wenhua yanjiu清代海 豐吳氏家族文化研究 [Research on the Culture of the Wu Clan from Qing Dynasty Haifeng]. Beijing: Zhonghua shuju.

Harper, Donald 1978. 'The Han Cosmic Board (Shih 式). Early China 4: 1-10.

Hegel, Robert E. 1998. Reading Illustrated Fiction in Late Imperial China. Stanford: Stanford University Press.

Heijdra, Martin J. 2006. 'A Tale of Two Aesthetics: Typography versus Calligraphy in the Pre-modern Chinese Book.' In: Ming Wilson and Stacey Pierson (eds.) The Art of the Book in China. London: University of London, Percival David Foundation of Chinese Art, School of Oriental and African Studies, 15-27.

Ho Peng Yoke 2003. Chinese Mathematical Astrology: Reaching Out to the Stars. London: Routledge. 
Ho Peng Yoke and Zhao Lingyang 1983. Ningwang Zhu Quan jiqi Gengxin yuce 寧王朱權及其庚辛玉冊 [The King of Ning Zhu Quan and His Gengxin yuce]. Australia: School of Modern Asian Studies; Hong Kong: Hong Kong University Chinese Department.

Hucker, Charles O. 1985. A Dictionary of Official Titles in Imperial China. Stanford: Stanford University Press.

Idema, Wilt 1986. 'Chu Chuan.' In: William H. Nienhauser (ed.) The Indiana Companion to Traditional Chinese Literature. Bloomington: Indiana University Press, 329.

Inoue Susumu 井上進 2006. Shorin no chōbō: dentō Chūgoku no shomotsu sekai 書林の眺望: 伝統中國 の書物世界 [A Panorama of the Forest of Books: The World of Books in Traditional China]. Tokyo: Heibonsha.

Jansen, Laura 2014. The Roman Paratext. Cambridge: Cambridge University Press.

Jiangxi sheng bowuguan 江西省博物館, Nancheng xian bowuguan 南城縣博物館, Xinjian xian bowuguan 新建縣博物館, and Nanchang shi bowuguan 南昌市博物館 2010. Jiangxi Mingdai fanwang mu 江西 明代藩王墓 [Kingly Tombs of Ming Dynasty Jiangxi]. Beijing: Wenwu chubanshe.

Jonker, D. R. 1976. ‘Chu-Ch’üan.' In: Carrington Goodrich (ed.) Dictionary of Ming Biography. New York and London: Columbia University Press, 305-7.

KÁDÁR Dániel Z. 2019. 'Relational Ritual Politeness and Self-Display in Historical Chinese Letters.' AOH 72/2: 207-227.

Kalinowski, Marc 2008. 'Le livres des jours (rishu) des Qin et des Han: la logique éditoriale du recueil a de Shuihuidi (217 avant notre ère)'. Toung Pao [Second Series 94] 1/3: 1-48.

Kalinowski, Marc 2013. 'The notion of 'shi' 式 and some related terms in Qin-Han calendrical astrology'. Early China 35: 331-60.

Karchmer, Eric I. and Volker Scheid 2014. 'History of Chinese Medicine, 1890-2010'. In: Vincent GoosSaert, Jan Kiely and John Lagerwey (eds.) Modern Chinese Religion II: 1850-2015. Leiden: Brill, 141-194.

Kleeman, Terry 1994a. A God's Own Tale: The Book of Transformations of Wenchang, the Divine Lord of Zitong. Albany, NY: State University of New York Press.

Kleeman, Terry 1994b. 'Licentious Cults and Bloody Victuals: Sacrifice, Reciprocity and Violence in Traditional China.' Asia Major, Third Series, 7.1, 185-221.

Kleeman, Terry 2016. Celestial Masters: History and Ritual in Early Daoist Communities. Cambridge and London: Harvard University Press.

Kreinath, Jens, Jan Snoek, Jan and Michael Stausberg (eds.) 2016. Theorizing Rituals: Issues, Topics, Approaches, Concepts. Leiden: Brill.

Lagerwey, John 2004. 'Deux écrits taoïstes anciens.' Cahiers d'Extrême Asie 14: 139-171.

Lagerwey, John 2016. 'The Ming Dynasty Double Orthodoxy: Daoxue and Daojiao.' Cahiers d'Extrême-Asie [special issue: Daoist Lives: Community and Place] 25: 113-129.

McDermotт, Joseph Peter 2006. A Social History of the Chinese Book: Books and lLterati Culture in Late Imperial China. Hong Kong: Hong Kong University Press.

Meulenbeld, Mark 2015. Demonic Warfare: Daoism, Territorial Networks and the History of a Ming Novel. Honolulu: University of Hawai'i Press.

Meulenbeld, Mark 2016. 'Daoist Modes of Perception: 'Registering' the Living Manifestations of Sire Thunder, and why Zhuang Zi is relevant.' Daoism: Religion, History and Society 8: 35-91.

Miller, Daniel (ed.) 2005. Materiality. Durham and London: Duke University Press.

Ming, Wilson and Stacey Pierson (eds.) 2006. The Art of the Book in China. London: University of London, Percival David Foundation of Chinese Art, School of Oriental and African Studies. 
Nickerson, Peter 1994. 'Shamans, demons, diviners, and Taoists: conflict and assimilation in medieval Chinese ritual practice.' Taoist Resources 5.1: 41-66.

Nothaft, C. Philipp E. 2014. Medieval Latin Christian Texts on the Jewish Calendar: A Study with Five Editions and Translations. Leiden: Brill.

Pregadio, Fabrizio 2006. Great Clarity: Daoism and Alchemy in Early Medieval China. Stanford: Stanford University Press.

Puett, Michael 2002. To Become a God: Cosmology, Sacrifice and Self-Divinization in Early China. Cambridge (Mass.) and London: Harvard University Press.

Puett, Michael 2010. 'Becoming Laozi: cultivating and visualizing spirits in early-medieval China'. Asia Major [Third Series] 23/1: 223-252.

QuACK, Johannes 2010. 'Bell, Bordieu, and Wittgenstein on Ritual Sense.' In: Johannes Quack, William S. Sax and Jan Weinhold (eds.) The Problem of Ritual Efficacy. Oxford: Oxford University Press, 169-88.

RAZ, Gil 2012. The Emergence of Daoism: Creation of a Tradition. New York: Routledge.

Robinet, Isabelle 1984. La Révélation du Shangqing dans l'histoire du taoïsme. Paris: École française d'extrême-Orient.

Robinson, David 2012. 'Kingly Courts of the Ming Dynasty.' Ming Studies 65: 1-12.

Schachter, Bony 2018a. Nanji Chongxu Miaodao Zhenjun: The Tianhuang zhidao taiqing yuce and Zhu Quan's (1378-1448) Apotheosis as a Daoist God. Ph.D. dissertation. Hong Kong: The Chinese University of Hong Kong.

Schachter, Bony 2018b. 'Printing the Dao: Master Zhou Xuanzhen, the Editorial History of the Jade Slips of Great Clarity and Ming Quanzhen Identity' Daoism: Religion, History, and Society 10: 1-86.

SCHIPPER, Kristofer and YuAn Bingling 2004. 'Tianhuang zhidao taiqing yuce.' In: Kristofer SchIPper and Franciscus Verellen (eds.) The Taoist Canon: A Historical Companion to the Daozang. Chicago: University of Chicago Press, 947-948.

SCHneEwind, Sarah 2008. Long Live the Emperor! Uses of the Ming Founder across Six Centuries of East Asian History. Minneapolis: Society for Ming Studies.

Shen, Grace Yen 2014. 'Scientism in the Twentieth Century.' In: Vincent Goossaert, Jan Kiely, and John Lagerwey (eds.) Modern Chinese Religion II: 1850-2015. Leiden: Brill, 91-137.

Sivin, Nathan 2015. Health Care in Eleventh-Century China. New York: Springer Media.

SKAR, Lowell 1997.'Administering Thunder: A Thirteenth-century Memorial Deliberating the Leifa.' Cahiers d'Extrême Asie 9: 159-202.

Steavu, Dominic 2019. The Writ of the Three Sovereigns: From Local Lore to Institutional Daoism. Hong Kong: The Chinese University Press.

STERn, Sacha 2001. Calendar and Community: A History of the Jewish Calendar, Second Century BCE-Tenth Century CE. Oxford: Oxford University Press.

Strickmann, Michael 1978. 'The Longest Taoist Scripture.' History of Religions 17: 331-354.

Strickmann, Michael 1981. Le Taoïsme du Mao Chan: chronique d'une revelation. Paris: Collège de France, Institut des hautes études chinoises.

Sutton, Donald S. 2003. Steps of Perfection: Exorcistic Performance and Chinese Religion in Twentieth-Century Taiwan, MA: Harvard University Asia Center.

Unschuld, Paul U. 2016. Huang Di Nei Jing Ling Shu: The Ancient Classic on Needle Therapy - The Complete Chinese Text with an Annotated English Translation. Berkeley: University of California Press.

Verellen, Franciscus 2004. 'The Heavenly Master Liturgical Agenda According to Chisong Zi's Petition Almanac.' Cahiers d'Extrême Asie 14: 291-343. 
Verellen, Franciscus 2019. Imperiled Destinies: The Daoist Quest for Deliverance in Medieval China. Cambridge and London: Harvard University Asia Center.

Wan, Chui Ki Maggie 2010. 'Daojiao banhua yanjiu: Daying tushuguan cang Yushu baojing si zhuben zhi niandai ji chahua kao 道教版畫研究: 大英圖書館藏《玉樞寶經》四註本之年代及插畫考 [Daoist Woodblock Prints: A Study of the Illustrations and Dating of the Glossed Yushu Baojing Collected in the British Library]'. Daoism: Religion, History, and Society 2: 135-183.

WANG, Richard 2012. The Ming Prince and Daoism: Institutional Patronage of an Elite. Oxford: Oxford University Press.

YAo Pinwen 姚品文 2002. Ningwang Zhu Quan 寧王朱權 [Zhu Quan, the King of Ning]. Seattle: Yishu yu renwen kexue chubanshe.

Zhang Chaojan 張超然 2008. Xipu, jiaofa jiqi zhenghe: Dongjin Nanchao daojiao Shangqing jingpai de jichu yanjiu 系譜、教法及其整合：東晉南朝道教上清經派的基礎研究 [Genealogies Teaching Methods and their Convergence: Fundamental Research on the Daoist Shangqing Sect of the Eastern Jin Dynasty]. Ph.D. Dissertation. Taibei: National Chengchi University.

Zhang, Fangjie 張芳杰 2003. Far-East Chinese-English Dictionary. New York: U.S. International Publishing Inc.

Open Access statement. This is an open-access article distributed under the terms of the Creative Commons Attribution-NonCommercial 4.0 International License (https://creativecommons. org/licenses/by-nc/4.0/), which permits unrestricted use, distribution, and reproduction in any medium for non-commercial purposes, provided the original author and source are credited, a link to the CC License is provided, and changes - if any - are indicated. 